\title{
Invertebrate predation on egg masses of the European cuttlefish, Sepia officinalis: an experimental approach
}

Catarina Padilha Pires Martins 



\section{Invertebrate predation on egg masses \\ of the European cuttlefish, Sepia officinalis: \\ an experimental approach}

Catarina Padilha Pires Martins

Directors

Roger Villanueva Fernando Fernández-Álvarez

Institut de Ciències del Mar, CSIC

Dissertation

Master's degree in Oceanography and Marine Environmental Management,

Universitat de Barcelona

October, 2016 



\begin{abstract}
Sepia officinalis embryos develop inside ink-stained black encapsulated eggs fixed to the seafloor in shallow water habitats. The enveloping layers of these eggs allow the embryo to develop within a micro-environment and are thought to provide protection. Since embryological development may last months, this short-lived species spends a relatively long period of its lifespan on shallow waters, vulnerable to predation and physical stress. Yet, only a handful of species are known to feed on S. officinalis eggs, most of them fish. Marine benthic invertebrates, however, are likely candidates contributing to predation of this critical life stage. In this study, several invertebrate marine species, from 6 different phyla and with diverse feeding habits, were investigated as potential predators of $S$. officinalis eggs under laboratory conditions. Feeding experiments also tested to what extent the egg capsule and lower levels of mechanical protection could deter predation and Multivariate Correspondence Analyses were performed to explore which feeding traits of the tested invertebrate species would explain the experimental results. Results showed predation on eggs by crabs and echinoderms equipped with certain prey capture methods that allowed them to feed on eggs. Also, the egg capsule appeared to provide protection from predation by certain species with less powerful prey capture tools. Prey capture tools of the tested species appeared to be the feeding trait that better explained the experimental results. Therefore, whether or not eggs were eaten in these experiments might be determined by a mechanical factor. Nonetheless this may not be the case for species that might not have fed on eggs due probably to a chemosensory question, not recognising them as food. This work thus contributes to the understanding of the ecology of early life stages of cuttlefish and the factors that can affect offspring survival and subsequently impact recruitment to the adult populations of this exploited species.
\end{abstract}




\section{ACKNOWLEDGMENTS}

This work might not have been possible without the support and help of many people. Many thanks to my directors, Fernando Fernández-Álvarez and Dr. Roger Villanueva, who taught me with patience and trusted me to embark on this study, while making the work truly feel like a journey of curiosity. Without their continuous guidance and encouragement this work would not have been the same.

I am grateful to John Ramírez, who helped me with the statistics and to make sense of them and who was always willing to discuss the work. Federico Quattrocchi also helped me with statistics and doubts that at the end of a long afternoon seem to have life of their own, thank you.

Thanks are due to Coral Hispano and also Lucía Carulla, from l'Aquàrium of Barcelona, for kindly providing cuttlefish egg masses and lending animals to test in the experiments. Also, to Alfredo García de Vinuesa, who provided many animals for experiments.

Thanks to Dr. Pere Abelló who helped me identify several crustacean species and provided insight into their biology. Also thanks to Dr. Montserrat Ramón for helping me identify the gastropod species and her willingness to discuss their biology and the experiments.

To Elvira Martínez, who provided technical help at the ZAE throughout the experiments whenever it was needed and taught me the art of keeping the water flowing through the pipes.

To the people in the department who helped me direct or indirectly in the development of this work. And my friends here and abroad who endured my conversations about the stunning cuttlefish and were an amazing audience to my narration of the storylines of the many animals.

Finally to my parents, for their support, love and understanding, among many more reasons, too numerous to write.

This study was funded by the research project CALOCEAN-2 (AGL2012-39077) from the MINECO. 


\section{INDEX}

1. INTRODUCTION 2

1.1. European cuttlefish Sepia officinalis 3

1.1.1. Reproduction and egg characteristics 3

1.1.2. Egg capsule characteristics 4

1.1.3. Embryological stage and egg predation 6

1.1.4. Hatching and the process of breaking through the physical barriers 7

2. OBJECTIVES

3. MATERIALS AND METHODS 7

3.1. Collection of animals $\quad 7$

3.2. Laboratory experiments $\quad 8$

3.2.1. Experimental design and procedure 8

3.3. Statistical analyses 12

3.3.1. Multivariate analysis 12

4. RESULTS 14

4.1. Feeding response of potential predators 14

4.2. Behavioural observations of potential predators 15

4.3. Capture tools of potential predators 16

5. DISCUSSION 17

5.1. The feeding biology of non-predators of Sepia officinalis eggs 17

5.2. The ambiguous case of the molluscan species 18

5.3. The feeding biology of potential predators of Sepia officinalis eggs 18

5.4. Egg capsule and chorion membrane protective features 20

6. CONCLUSION 22

7. REFERENCES 22

8. APPENDIX 29

8.1. Appendix references 46 


\section{INTRODUCTION}

Predation is an important source of egg mortality for many animals (Orians \& Janzen 1974) and encapsulation of eggs is a common protection strategy among marine invertebrates (Roche et al. 2011). While some animals appear to be specialists at eating eggs, almost all carnivores and many omnivores include several kinds of eggs in their diets (Orians \& Janzen 1974). For instance, the nemertean Carcinonemertes regicides is a well-documented egg predator (Kuris et al. 1991) and certain echinoderms and crabs feed on gastropod eggs (Bigatti et al. 2010, Dumont et al. 2008, Perron 1981). Generally, large eggs with longer developmental periods require more protection than small, more quickly-developing ones (Perron 1981). Therefore, egg capsule walls with strong structures, which constitute an energetic cost, may have evolved as a result of selection for improved protection of embryos from predation and physical stress during a protracted period of development (Perron 1981). Additionally, in coastal environments, egg capsules also protect embryos from various environmental stresses, bacterial attack and wave action (Roche et al. 2011).

Cephalopods display a diversity of egg morphologies, structure and size and in most cases the eggs are relatively well protected by encapsulation (Boletzky 2003). Cephalopod embryos are generally not viable if they are not properly protected and primary protection is provided by the chorion membrane, which is considered insufficient by itself (Boletzky 2010). Therefore, protection might be ensured through other means. In benthic and bentho-pelagic cephalopods, this protection is provided mainly in two ways: hard egg capsules that envelope eggs that develop without maternal care or egg brooding, a form of active protection in which the female stays with the eggs during their entire development while also ensuring that the conditions are favourable (Boletzky 1986). In fact, cephalopods with brooding include only a few oegopsid squid species and all incirrate octopods. Incirrate octopods are the only cephalopod group that does not have additional protective structures other than the chorion membrane, whereas all other cephalopods appear to have eggs also enwrapped and protected by capsules or jelly masses, which constitute the most important barrier against environmental damages (Boletzky 1998). 


\subsection{European cuttlefish Sepia officinalis}

Cuttlefish are among the most important commercial cephalopod resource in European waters and although several species are present in the north-east Atlantic, landings of the European cuttlefish Sepia officinalis dominate (Bloor et al. 2013). Additionally, S. officinalis is used as an animal model for biological and biomedical research, is recognised as a species with great potential for aquaculture and is used for public exhibition in aquariums (Sykes et al. 2014). Its distribution extends through the Mediterranean Sea and the waters of the north-eastern Atlantic to the north-western coast of Africa (Bloor et al. 2013). It is a nektobenthic species that lives in habitats with sandy, muddy and rocky substrate from the coastline $(2-3 \mathrm{~m}$ depth) to depths of up to $200 \mathrm{~m}$ (Bloor et al. 2013, Guerra 2006). It belongs to one of the few cephalopod groups with a chambered shell, known as cuttlebone in Sepia, a rigid calcium carbonate structure responsible for buoyancy control that also limits its depth range (Sherrard 2000).

\subsubsection{Reproduction and egg characteristics}

Sepia officinalis generally has an annual lifespan, ranging from 12 to 18 months (Guerra 2006) and is categorised as an intermittent spawner, having a single spawning period that occurs at the end of its life cycle (Rocha et al. 2001). Spawning is temperature dependent, occurs in shallow coastal waters between 5 and $60 \mathrm{~m}$ depth (Guerra et al. 2016) and its duration may vary over the geographical range of the species (Bloor et al. 2013).
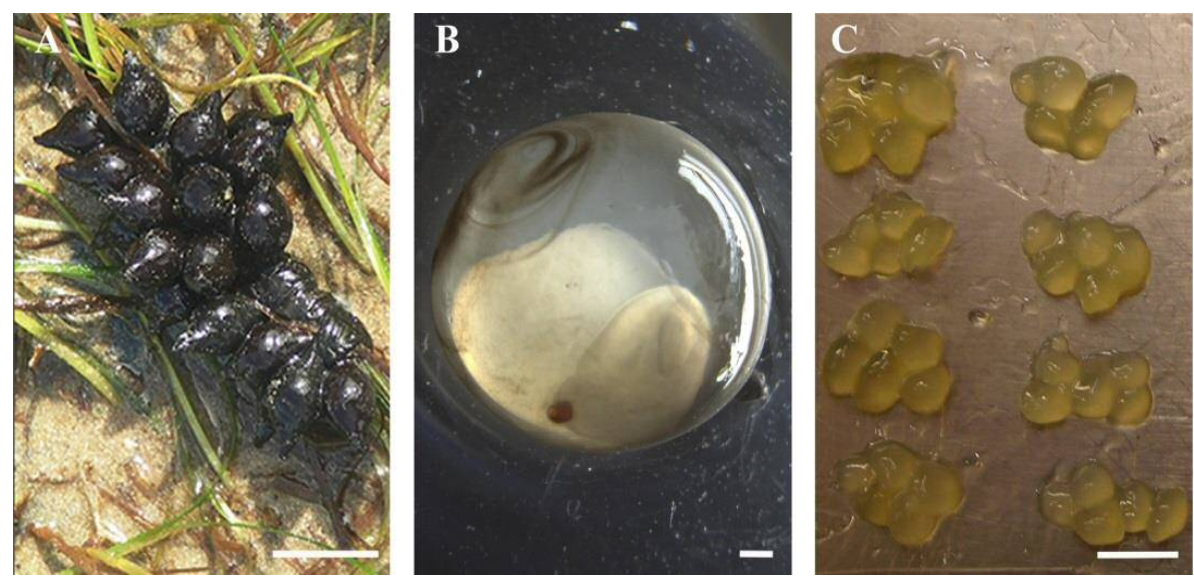

Fig. 1. Sepia officinalis. (A) Eggs in their natural condition (with egg capsule). (B) Egg without egg capsule; embryo is surrounded by the chorion membrane. (C) Mature oocytes. A, C scale bars: 1 cm. B scale bar: $1 \mathrm{~mm}$. 
Sepia officinalis lays eggs individually in clusters attached to a variety of fixed natural substrates (Fig. 1A) such as plants, algae, sessile animals, moving animals and previously deposited cuttlefish eggs, or even, when available, artificial substrates, typically fishing traps or nets (Bloor et al. 2013, Lacoue-Labarthe et al. 2016).

The process of spawning (illustrated in Fig. A1A) starts with the maturation of oocytes, cells $\sim 7 \mathrm{~mm}$ in size (Laptikhovsky et al. 2003), in the female ovary, where follicular cells secrete the chorion membrane, which surrounds mature oocytes and constitutes the first envelope of the egg (Boletzky 1986). These oocytes are then released through the oviduct and, after mating occurs, are transported by contractions of the distal oviduct and released individually into the mantle cavity (Zatylny et al. 2000). Here, each mature oocyte receives a first gelatinous envelope secreted by the oviducal glands, followed by a second gelatinous envelope composed of several layers secreted by the nidamental glands and stained with ink released by the ink sack (Boletzky 1986, Cornet et al. 2015, Zatylny et al. 2000). These envelopes constitute what is known as the egg capsule. The enveloped oocytes then proceed into the funnel tube and are brought to the base of the ventral arms, close to the mouth (Zatylny et al. 2000). Spermatozoids, which are stored in special structures under the buccal mass of the female, are then released and fertilization occurs (Zatylny et al. 2002). To fertilize the oocyte, the spermatozoid crosses the freshly produced jelly envelopes that surround the oocyte, which are soft and gelatinous prior to fertilization (Boletzky 1986, Zatylny et al. 2002). Following fertilization, the perivitelline fluid (PVF) is formed and numerous changes are triggered in these envelopes, which allow the creation of a micro-environment for embryological development (Boletzky 2003, Cronin \& Seymour 2000). The embryo has an embryological life that can be divided into 30 stages (Boletzky et al. 2016) and develops bathed in the PVF and surrounded by the chorion membrane and the egg capsule (Fig. A1B), which provide physical and chemical protection against the surrounding environment (Cornet et al. 2015, Lacoue-Labarthe et al. 2016). Nevertheless, the encapsulation of embryos within these protective layers comprises a considerable energetic investment by the female (Boletzky 2003).

\subsubsection{Egg capsule characteristics}

To deposit each egg, the female uses the arm tips to pull the gelatinous egg envelope secreted by the nidamental glands into two filaments and wraps them around the 
substrate, forming a ring that fixates the egg (Boletzky 1983, Boletzky 1986) (Fig. 1). Freshly laid eggs are soft and gelatinous (Boletzky 1983) and the egg capsule quickly hardens and becomes thicker (Lacoue-Labarthe et al. 2016). The initial thickness is approximately $1.5 \mathrm{~mm}$ and then decreases throughout embryonic development, while still retaining elasticity to allow for embryonic growth (Cornet et al. 2015, Wolf et al. 1985). Although the egg capsule allows for oxygen diffusion throughout embryological development, it acts as a shielding barrier for most of this period hindering the penetration of contaminants and most metallic ions within the egg (Lacoue-Labarthe et al. 2016). However, during the last third of embryological development, coinciding with the highest embryonic oxygen demands, this structure becomes more permeable due to the expansion of the egg capsule (Fig. A2D), caused by the embryo release of solutes into the PVF that create an osmotic pressure and provoke a substantial volume increase of the PVF (Cronin \& Seymour 2000).

The ultrastructure of the egg capsule reveals an organised network of glycoproteins and polysaccharides with elasticity and resistance properties (Cornet et al. 2015). Within this network, melanin deposits and symbiotic bacteria are also found (Cornet et al., 2015). Melanin is one of the main components of cephalopod ink, comprising $15 \%$ of its total wet weight (Derby 2014). Cephalopod ink has been proposed as an aversive deterrent of predators or a disruptor of chemical senses of predators and is thought to defend cephalopods against them in a variety of ways (Derby 2014). For instance, it has been proposed as phagomimetic defence due to its high levels of amino acids, which are strong phagostimulants of marine predators (Derby 2014). On the other hand, ink from two squid species has been shown to be unpalatable to predatory fish (Derby 2014) and it has been speculated that quinones, which are often used as chemical defenses by animals, might constitute the feeding deterrents in Sepia ink (Prota et al. 1981). Furthermore, the mentioned symbiotic bacteria populations lodged within the egg capsule, found also in eggs of other cephalopod species, are thought to provide protection throughout the embryological development by inhibiting colonization of other bacteria or actively producing antimicrobial substances (Biggs \& Eppel 1991, Cornet et al. 2015). In addition, egg capsule proteins also appear to have antimicrobial and antifouling properties (Cornet et al. 2015). Nevertheless, it should be noted that the chemical composition of the egg capsule is still largely unknown (Boletzky et al. 2016). 


\subsubsection{Embryological stage and egg predation}

Sepia officinalis eggs, measuring $\sim 20 \mathrm{~mm}$ length and $\sim 10 \mathrm{~mm}$ diameter (Boletzky 1983), are among the largest cephalopod eggs (Boletzky 1983) and because these are attached to structures on the seabed, they stay on the same space a significant period of time. In result, their development is dependent on the surrounding spawning ground conditions and so, the spawning site can affect dramatically the survival and fitness of offspring (Bloor et al. 2013). However, the process by which sexually mature Sepia females select their spawning habitat is unknown (Bloor et al. 2013).

Duration of egg development varies with water temperature, ranging from approximately one month at $25^{\circ} \mathrm{C}$ to three months at $15^{\circ} \mathrm{C}$ (Boletzky 1983, Lemaire 1970). For this short-lived species, this constitutes a relatively long period of its lifespan (Lacoue-Labarthe et al. 2016). No parental care has been reported in this species and yet no major predation pressure on the eggs has been reported either (Guerra 2006). Nonetheless, a limited number of predation events on Sepia eggs in the wild have been documented. On S. officinalis eggs, predation has been observed in the Ria de Vigo (north-eastern Atlantic) by the Tomblot blenny Parablennius gattorugine (Guerra \& González 2011), in Morbihan Bay (north-eastern Atlantic) by the triggerfish Balistes capriscus (Blanc \& Daguzan 1999) and in the north-western Adriatic Sea by the gastropod Hexaplex trunculus (Melli et al. 2014). On Sepia pharaonis eggs, predation has been observed in the Arabian Sea by the fish families Chaetodontidae, Balistidae, Monacanthidae and Zanclidae (Gutsal 1989). On Sepia latimanus eggs, predation has been observed in Guam (south Pacific) by the butterfly fish Chaetodon ulietensis (Corner \& Moore 1980). The few works that look at egg predation is noticeable but it is also interesting to note the almost complete absence of invertebrates from these accounts. Although a rich diversity of benthic invertebrates are bound to encounter the conspicuous siting targets that are the black masses of Sepia eggs, only one invertebrate species is mentioned.

Interestingly, other Sepia species with unstained egg capsules do show behaviours during spawning that provide complementary egg protection against predators. For instance, Sepia orbignyana females insert eggs into the oscula of sponges, which provide camouflage (Boletkzy 1986), Sepia elegans females fix their eggs on braches of octocorallians so polyps surrounding the egg may protect it (Boletzky 1986) and $S$. 
latimanus places its eggs in crevices (Corner \& Moore 1980). Furthermore, during this embryological stage, development and growth of the embryo is fuelled by energetic reserves stored as yolk, a nutritious structure rich in proteins, carbohydrates and lipids (Matozzo et al. 2015) and of which S. officinalis embryos are provisioned generously (Boletzky 2003). Therefore, eggs would be rather nutritious targets for predators.

\subsubsection{Hatching and the process of breaking through the physical barriers}

Since $S$. officinalis embryos develop within this physical barrier composed by the chorion membrane and the egg capsule, they have strategies to penetrate and hatch through these relatively thick envelopes at the end of embryonic development. This is accomplished mainly by the Hoyle organ; a hatching gland located on the posterior tip of the mantle that releases enzymes that digest the chorion membrane and the egg capsule, combined with muscular contractions of the mantle (Cyran et al. 2013). In Sepia, the Hoyle organ consists of thin bands of glandular cells with globular secretory granules that are released individually by exocytosis and densely ciliated non-secretory cells (Cyran et al. 2013). However, which types of enzymes are involved in the digestion of the chorion and the capsule remains unclear (Cyran et al. 2013). Also, egg capsule proteins might be cleaved to allow hatching (Cornet et al. 2015).

\section{OBJECTIVES}

Experiments were set up to investigate potential natural predators of the cuttlefish Sepia officinalis eggs and explore to what extent the egg capsule and lower levels of mechanical protection can deter their predation.

\section{MATERIALS AND METHODS}

\subsection{Collection of animals}

Cuttlefish (Sepia officinalis) eggs were obtained from egg masses spawned in the laboratory by captive adults collected from the artisanal fishery of Vilanova i la Geltrú, NW Mediterranean, from February to April of 2016, and maintained at the Zona de Acuarios Experimentales (ZAE) of the Institut de Ciències del Mar (ICM). Additional egg masses spawned in aquaria were also provided by the public aquarium of Barcelona (l'Aquàrium). During the experimental period, egg masses were incubated at a temperature of $14 \pm 1{ }^{\circ} \mathrm{C}$, (ranging from $12-17^{\circ} \mathrm{C}$ ). Egg mases were incubated 
attached to the structure used by the female to spawn, usually plastic ropes; isolated eggs were incubated inside laboratory tanks (see below) using plastic, perforated floating containers.

Potential predator specimens were obtained from different sources: local trawler fishery of Blanes and Vilanova i la Geltrú (NW Mediterranean), fishery and bait markets, collected directly from nature (Muros de Nalón, NE Atlantic) and some of them were also provided by l'Aquàrium. A total of 22 invertebrate species, representing 6 different animal phyla (Cnidaria, Nemertea, Mollusca, Annelida, Arthropoda and Echinodermata), were tested as potential predators (Fig. A3). The number of the animals tested per species, mean fresh body size and weight, origin and collection method of specimens is presented in Table A1. Potential predators were selected to represent a wide taxonomic range with different feeding diets and habits and that could come across egg masses of $S$. officinalis in their natural habitat (Table A2). Bathymetric and feeding characterization of these species is summarized in Table A2.

\subsection{Laboratory experiments (Fig. 2A)}

Experiments were conducted at the ZAE from April 26 to August 3, 2016. Potential predators were placed in chambered cages $(47 \times 45 \times 26 \mathrm{~cm})$ of green wire mesh of $10 \mathrm{x}$ $10 \mathrm{~mm}$ (Fig. A4A), preventing the escape of animals and ensuring adequate water circulation, inside 1201 tanks $(116 \times 71 \times 21 \mathrm{~cm})$ supplied with running fresh seawater

$\left(5.51 \cdot \mathrm{min}^{-1}\right)$. Cages were opened from the top and had the bottom reinforced with a green plastic mesh of $1 \times 1 \mathrm{~mm}$. During the experiments, a dark net was placed on top of the experimental cages to avoid potential escapes and minimize light disturbances. Cages and tanks were both cleaned before each experiment. All animals were kept under natural photoperiod and water temperature was $16 \pm 1{ }^{\circ} \mathrm{C}$ (ranging from 13 to 18 $\left.{ }^{\circ} \mathrm{C}\right)$.

\subsubsection{Experimental design and procedure}

Potential predators were placed individually in the chambers $(23 \times 14 \times 25 \mathrm{~cm})$ and animals bigger than the experimental chambers were placed instead in baskets $(31 \times 23$ x $20 \mathrm{~cm}$ ) (Fig. A4B), where the experiments were performed following the same methodology. Feeding experiments consisted of presenting potential predators with three food options (Fig. 1): (a) 5 cuttlefish eggs with capsule (EC), (b) 5 cuttlefish eggs 
without capsule (EWC) and (c) 5 cuttlefish mature oocytes. These food options have a similar biochemical composition and represent decreasing degrees of mechanical protection, due to the different properties of its outer physical barrier; solid, turgid and flaccid correspondingly. EC are the natural condition of $S$. officinalis eggs and have a solid physical barrier (the egg capsule), which represents the highest degree of protection in this experimental design. EWC are protected by the expanded chorion membrane onset by fertilization and the emergence of the perivitelline fluid and its subsequent incorporation of water (Boletzky 2003). At this stage, the chorion membrane constitutes a turgid physical barrier due to the tensional strain created by the perivitelline fluid, which in turn provides and maintains the rigidity of the membrane. To obtain EWC, the egg capsule was removed by hand to its maximum extent, taking care not to rupture the chorion membrane or weaken it so much that it might rupture spontaneously. Since it was logistically impossible to present all test animals with eggs of identical developmental stage, a developmental stage range was used. Following the embryological developmental stages proposed by Boletzky et al. (2016), potential predators were presented with eggs at stages 21-28 (Fig. A2A-C). OO are cells whose outer layer is the chorion membrane prior to its expansion and the changes caused by fertilization and embryological development. Therefore, OO are surrounded by a flaccid physical barrier, which represents the lowest level of protection in this experimental design. Unlike EC and EWC, OO are not a balloon-like structure and from a mechanical perspective, are also easier to manipulate underwater. OO were obtained from the ovary of a dissected $S$. officinalis mature female.

Potential predator individuals were presented with either of the three food options (EC, EWC, or OO) and were used only once. Prior to running the experiments, potential predators were starved for at least $48 \mathrm{~h}$. In the case of a few of the animals, their condition was assessed prior to the experiments by offering a small piece of mantle tissue of mussel. Having eaten the offered piece of mussel, these individuals were then placed in starvation before starting the experiment. Animals that did not eat the food option of the experiment were assessed visually or by offering some other piece of food more attractive to the animal after the experiments. Experiments lasted for $48 \mathrm{~h}$ or until all food items had been eaten. Animals were observed throughout the experiments during daytime hours and a few predation events were recorded. In the case of 
Astropecten aranciacus, feeding of EC was purposefully recorded in a glass aquarium $(28 \times 22 \times 15 \mathrm{~cm})$ with running fresh seawater.

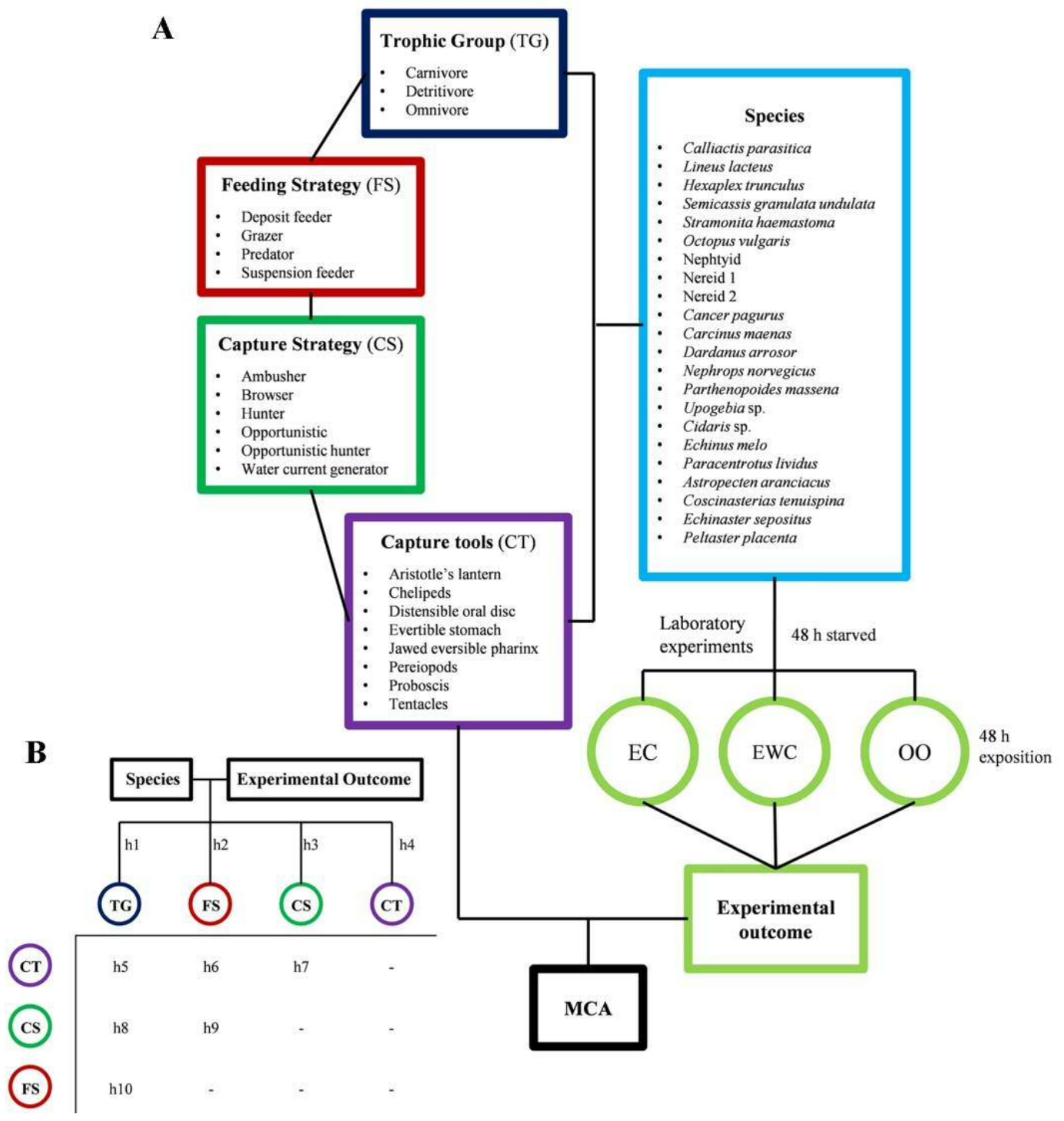

Fig. 2. Diagrams of the study. (A) Diagram outlining the global structure of the study. Square box in light blue indicates the species tested as potential predators of Sepia officinalis eggs in laboratory. Circular boxes represent the laboratory experiments and squared boxes represent the variables used in the MCA analyses. Squared boxes colour coded represent the four biological categories (and its corresponding levels) used to characterize the feeding biology of the tested potential predator species. (B) Diagram outlining the construction of all 10 hypotheses from combinations of variables to perform the MCA analyses. Black boxes represent the 2 variables used in all analyses. Circular boxes represent the other 4 biological variables (colour coded) considered as potentially explanatory of the experimental results and that differed between hypotheses. (CS, capture strategy; CT, capture tools; EC, egg with capsule; EWC egg without capsule; FS, feeding strategy; h1, hypothesis 1; h2, hypothesis 2; hypothesis 3 ; and so on; MCA, Multivariate Correspondence Analysis; OO, oocytes; TG, trophic group). 
At the end of each experiment, the number of eggs was counted and the potential predator subjects were measured (see Table A3 for the definition of the body size measurement used to characterize each species) and weighed. EC with visible marks on the surface of the capsule were examined under binocular microscope and when EC were ruptured, these were opened to check whether the embryo was still inside. Video recordings of the predatory behaviour were obtained using a video camera SAVFY SJ4000 1080P. Although 22 potential predator species were tested in total, only 16 of these were presented with all 3 options of the feeding experiment due to insufficient individuals available to perform all trials. This meant that, for example, none of the molluscan species was tested against the complete feeding experiment. A few modifications were made to the standard methodology to adapt it to the biological diversity of our experimental potential predatory subjects, in particular for the species Calliactis parasitica, Lineus lacteus, Octopus vulgaris, the nephtyid and nereid polychaetes and Upogebia sp.

\section{Anemone Calliactis parasitica}

This anemone was selected as a potential predator due to a previous observation of a predatory behaviour on $S$. officinalis eggs during its mutualistic association with the crab Dardanus arrosor. Individuals of $C$. parasitica were carefully removed from the shell of $D$. arrosor individuals and placed each in a glass Petri dish (14 cm diameter). The Petri dishes were then placed inside the experimental chambers, where the experiments were performed. In this case, we waited until individuals had the oral disc open and then offered to the anemone 1 EC, 1 EWC or 1 OO depending on the experiment, by dropping it gently by hand over the oral disc. We then observed the behaviour of the animals and their initial reaction to the food items was video recorded. Experiments were considered complete when the anemone consumed the offered item and for those that did not do so on first contact, experiments lasted for $48 \mathrm{~h}$ during which the egg offering operation was repeated 7-10 times.

\section{Nemertean Lineus lacteus and the nereid polychaetes}

Due to the small size and admirable escape behaviour of the nemertean L. lacteus and nereid polychaetes, the experiments with these animals were performed in closed 0.61 plastic containers (Fig. A4C) filled with fresh seawater, which was renewed daily. The 
experiments were then conducted in the same manner as those described in the standard methodology.

\section{Common octopus Octopus vulgaris}

The feeding experiment performed with $O$. vulgaris followed the same design as the standard methodology described above, but took place in a 25001 circular tank with running fresh seawater, where the individual had been maintained and was fed daily live Carcinus maenas crabs. Before initiating the experiment, the tank was cleaned and the octopus was starved for $48 \mathrm{~h}$. After the presentation of the EC, the animal was recorded and it was then checked on periodically throughout the experiment.

Nephtyid polychaete and the mud lobsters Upogebia sp.

Because the nephtyid polychaetes and the mud lobster Upogebia sp. are small in size (Table A1), the designed chambered cages of the standard methodology were useless to hold the animals and prevent their escape. These were placed in 0.61 plastic containers (Fig. A4C) with round openings covered with a $500 \mu \mathrm{m}$ net and were submerged in the tanks used in the standard methodology. This design allowed a continuous flow of water while also preventing the escape of the animals. Otherwise, the experiments were performed following the standard methodology.

\subsection{Statistical analyses}

Chi-square analyses on the number of consumed EC, EWC and OO were performed for all animals tested, for the phylum Arthropoda and for the phylum Echinodermata. Consumption of EC among phyla was also tested using a chi-square test. Tests among species and of the consumption of EWC and of $\mathrm{OO}$ for arthropods and for echinoderms were not possible to perform due to small sample size. Chi-square analyses were performed using JMP statistical software.

\subsubsection{Multivariate analysis (Fig. 2A)}

Multivariate Correspondence Analyses (MCA) were performed to explore which traits or combination of traits, if any, could explain the experimental results obtained in laboratory. An MCA is a multivariate statistical analysis equivalent to a Principal Component Analysis (PCA) but for categorical variables. However, contrary to PCA, 
the variance explained by each MCA axis has no significant meaning and should not be taken into account (Telechea et al., 2009).

The experimental results were grouped into a variable named 'Experimental outcome' and coded as EC, EWC and OO (which corresponded to eating the food option EC, EWC or OO offered) and as No EC, No EWC and No OO (which corresponded to not eating the food option offered). Only the results of species tested with all 3 food options of the experiment were used for this analysis. Feeding biology of the tested species was characterised using 4 biological categories: trophic group (TG), feeding strategy (FS), capture strategy (CS) and capture tools (CT). Each category had several levels to which a species was assigned. Levels corresponded to functional attributes that grouped species within each biological category. For example, the category TG was composed by the functional groups; carnivore, detritivore and omnivore. A definition of the levels of each category, as used in this study, is provided in Table A4. Classification of the species within the categories was done based on the literature. When a species was known to have several traits or strategies of the same biological category, the predominant one was chosen.

The biological categories, the species and the experimental outcome were used to construct a categorical matrix. Species and experimental outcome were analysed with one or 2 of the biological categories at a time. This resulted in a total of 10 different combinations of variables which were considered as hypotheses (Fig. 2B). For example; hypothesis 1 (h1) assumed that the trophic group was the biological category that better explained the experimental results and the matrix for this MCA analysis was constructed using the variables; species, experimental outcome and trophic group. An MCA was performed for each hypothesis. Rejection of a hypothesis was determined visually based on the resulting MCA graph. No analyses were performed using more than 2 biological categories because when we performed MCA analyses using 2 biological categories, which in our study corresponded to the hypotheses 5 through 10 (h5 - h10) (Fig. Y2), the levels of the variable 'experimental outcome' were plotted with little association to the variable 'species' and to the other variables used. Thus, we considered this to be a sign that, in these analyses, the weight of the two biological categories was higher than the results of the experiment and therefore were not being reflected. For this reason, we considered that MCA analyses carried out with three or 
more of the biological variables would lead to this same situation. MCA analyses were performed using the R package FactoMineR (Lê et al., 2008).

\section{RESULTS}

\subsection{Feeding response of potential predators}

Consumption of the three types of food offered (EC, ECW and OO) was significantly different among the potential predators tested $\left(\chi^{2}=62.13, p<0.0001\right)$. Of the 22 potential predator species, 13 ate none of the options presented in the feeding experiments and 9 ate two or more options (Table 1).

Table 1. Number of individual potential predators used and percentage of individuals that consumed eggs, eggs without capsule and oocytes per species. (EC, eggs with capsule; EWC, eggs without capsule; n, number of animals tested; N/A, not applicable; OO, oocytes). *Species with insufficient individuals to perform complete experiments.

\begin{tabular}{|c|c|c|c|c|c|c|}
\hline & \multicolumn{2}{|c|}{$\mathrm{EC}$} & \multicolumn{2}{|c|}{ EWC } & \multicolumn{2}{|c|}{$\mathrm{OO}$} \\
\hline & $\mathrm{n}$ & $\%$ & $\mathrm{n}$ & $\%$ & $\mathrm{n}$ & $\%$ \\
\hline Calliactis parasitica & 2 & 0 & 2 & 50 & 2 & 100 \\
\hline Lineus lacteus & 2 & 0 & 2 & 0 & 1 & 0 \\
\hline Hexaplex trunculus* & 1 & 0 & 0 & N/A & 0 & N/A \\
\hline $\begin{array}{l}\text { Stramonita } \\
\text { haemastoma* }\end{array}$ & 0 & N/A & 1 & 0 & 0 & N/A \\
\hline $\begin{array}{l}\text { Semicassis granulata } \\
\text { undulata* }\end{array}$ & 1 & 0 & 0 & N/A & 0 & N/A \\
\hline Octopus vulgaris* & 1 & 0 & 0 & N/A & 0 & N/A \\
\hline Nephtyid & 3 & 0 & 3 & 0 & 3 & 0 \\
\hline Nereid 1 & 4 & 0 & 4 & 0 & 4 & 0 \\
\hline Nereid 2 & 4 & 0 & 4 & 0 & 4 & 0 \\
\hline Cancer pagurus & 2 & 100 & 2 & 50 & 2 & 100 \\
\hline Carcinus maenas & 5 & 0 & 5 & 100 & 5 & 100 \\
\hline Dardanus arrosor & 4 & 75 & 4 & 100 & 4 & 100 \\
\hline Nephrops norvegicus & 3 & 0 & 3 & 66,7 & 3 & 100 \\
\hline $\begin{array}{l}\text { Parthenopoides } \\
\text { massena }\end{array}$ & 1 & 0 & 1 & 0 & 1 & 0 \\
\hline Upogebia sp. & 4 & 0 & 4 & 0 & 4 & 0 \\
\hline Cidaris sp. & 3 & 33,3 & 3 & 66,7 & 3 & 66,7 \\
\hline Echinus melo & 4 & 100 & 4 & 100 & 4 & 100 \\
\hline Paracentrotus lividus & 2 & 100 & 1 & 0 & 1 & 100 \\
\hline Astropecten aranciacus & 1 & 100 & 1 & 0 & 1 & 100 \\
\hline $\begin{array}{l}\text { Coscinasterias } \\
\text { tenuispina* }\end{array}$ & 1 & 0 & 0 & N/A & 0 & N/A \\
\hline Echinaster sepositus & 2 & 0 & 2 & 0 & 2 & 0 \\
\hline Peltaster placenta* & 1 & 0 & 0 & N/A & 0 & N/A \\
\hline
\end{tabular}


The species with only negative outcomes were the nemertean L. lacteus $(n=12)$, the polychaetes Nephtyid $(n=9)$, Nereid $1(n=12)$ and Nereid $2(n=12)$, the arthropods Parthenopoides massena $(n=3)$ and Upogebia sp. $(n=12)$ and the echinoderms Coscinasterias tenuispina $(n=1)$, Echinaster sepositus $(n=6)$ and Peltaster placenta $(n$ =1) (Table 1). None of the molluscan species tested consumed EC, which included the species Hexaplex trunculus $(n=1)$, Stramonita haemastoma $(n=1)$, Semicassis granulata undulata $(n=1)$ and O. vulgaris $(n=1)$ (Table 1). Nevertheless, the $H$. trunculus and S. granulata undulata species showed predation on EC when the exposition time was longer (11 days in total). The experiments with positive predatory outcomes belonged to the anemone $C$. parasitica $(n=6)$ and the remaining 6 arthropod $(n=57)$ and 7 echinoderm species $(n=36)$ (Table 1; Fig. A5). In these experiments, all species consumed OO and both the arthropods $\left(\chi^{2}=69.28, p<0.0001\right)$ and echinoderms $\left(\chi^{2}=11.20, p<0.0001\right)$ showed significant differences for consuming the 3 food types offered. Predation on EC differed significantly between phyla $\left(\chi^{2}=37.04, p<0.0001\right)$.

The sea urchin Echinus melo $(n=12)$ was the only species for which all individuals consumed both EC (Fig. A6F) and EWC. The crab Cancer pagurus $(n=6)$, the hermit crab D. arrosor $(n=12)$ (Fig. A6B) and the sea urchin Cidaris sp. $(n=9)$ also consumed both treatments but showed more variability among individuals. For instance, only $75 \%$ of $D$. arrosor and $33 \%$ of Cidaris sp. individuals consumed EC. EWC were consumed by $67 \%$ of Cidaris sp. and by $50 \%$ of C. pagurus. The species Paracentrotus lividus $(n=4)$ and A. aranciacus $(n=3)$ (Fig. A6E) also consumed EC, but did not eat EWC. On the other hand, EWC were also consumed by $C$. parasitica, the crab Carcinus maenas $(n=15)$ and the lobster Nephrops norvegicus $(n=9)$. Whereas all C. maenas individuals consumed EWC, only $50 \%$ and $67 \%$ of $C$. parasitica and $N$. norvegicus did so, respectively. These species did not consume EC.

\subsection{Behavioural observations of potential predators}

Although $C$. parasitica did not eat EC in the experiments, the individuals seemed to explore the EC before eventually rejecting it. On the other hand, the individuals of this species that ate EWC and OO started swallowing the item shortly after being offered. The $O$. vulgaris and P. placenta individuals both appeared to briefly explore the EC when offered, but did not seem further interested during the rest of the experiment. The species $C$. maenas and $N$. norvegicus were observed attempting to prey on EC but failed 
to rupture the capsule, which showed clear marks on its surface at the end of the experiments. Some individuals of $N$. norvegicus also appeared to show some struggle to manipulate and consume EWC during their first attempts because EWC slipped from the grasp of chelipeds and due to the movement of these appendages the EWC might bounce and swing in the water. Sea urchins generally consumed all 5 EC offered in the experiment. However when this was not the case, the EC not consumed also showed marks on the external surface of the egg capsule. A. aranciacus was observed ingesting an EC (Fig. A6E) by swallowing it whole and regurgitated a cuttlebone (after 18 days) (Fig. A6D) and shells (Fig. A6C), the latter surely ingested before the experiment.

\subsection{Capture tools of potential predators}

MCA analyses for all hypotheses showed that the biological trait that seemed to better explain the results obtained in the laboratory experiment was the one performed with the variable 'capture tools' (h4) (Fig. 3).

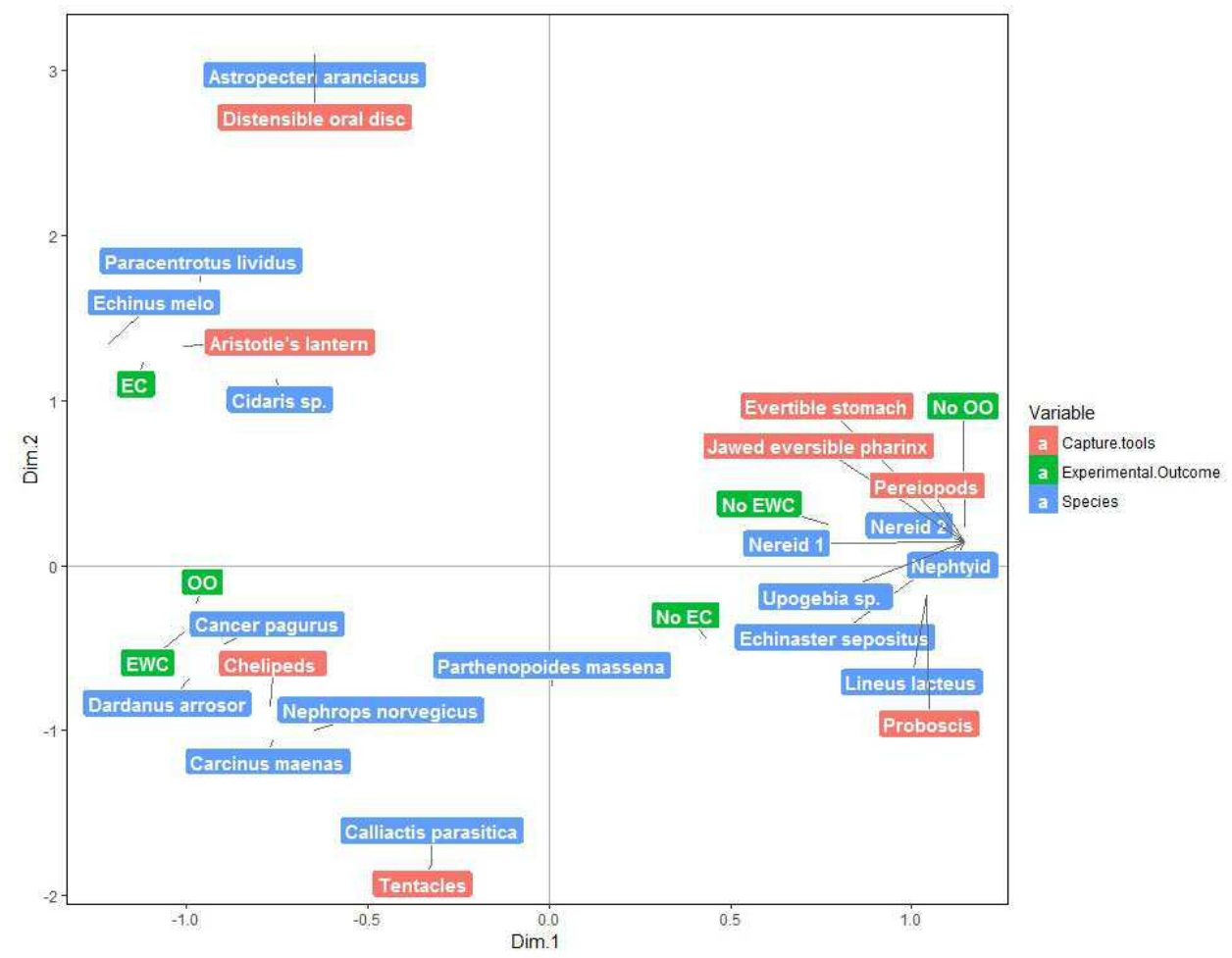

Fig. 3. Multivariate Correspondence Analysis of hypothesis 4; testing the laboratory results (represented by the variable Experimental outcome) per species, with the biological category Capture tools. (EC, eggs with capsule consumed; EWC, eggs without capsule consumed; OO, oocytes consumed; No EC, eggs with capsule not consumed; No EWC, eggs without capsule not consumed, No OO, oocytes not consumed). 
MCA analyses performed with the variables for the other hypotheses did not group species taking into account the laboratory experiment and were rejected (Fig. A7). In the graph of the MCA (Fig. 3) performed with the variable 'capture tools', two main groups of species can be identified along the first axis. One group, located on the right part of the diagram, is characterised by not eating any of the food options of the experiment and the second group, located on the left part, is characterised by eating at least some of the food options. Within this group along the second axis, the species with chelipeds appear to be more associated with eating EWC and OO, whereas the species with an Aristotle's lantern or a distensible oral disc seem more related with eating EC.

\section{DISCUSSION}

Although predation might be an important threat for many benthic marine egg masses (Dumont et al. 2008), no major predation pressure has been reported for the relatively large eggs of the European cuttlefish S. officinalis (Guerra 2006). In this study, an experimental approach was used to expressly investigate this and results have showed that predation on egg masses of $S$. officinalis by benthic marine invertebrates may be possible. Mainly only crabs, sea urchins and a starfish (A. aranciacus) fed on $S$. officinalis eggs under our experimental conditions.

\subsection{The feeding biology of non-predators of Sepia officinalis eggs}

In our experiments we found that a diverse group of the tested species did not feed nor show interest for any of the food offered (EC, EWC or OO). This seems to indicate that this type of food material was not attractive to them. However, egg masses provide a rich source of nutrition and in particular, Sepia eggs are very rich in yolk, which represents approximately $13 \%$ of the total egg weight and, in essence, is a storage of energy rich in proteins, carbohydrates and lipids (Matozzo et al. 2015, Sykes et al. 2009). On the other hand, although this type of food material could have been edible for them, they might not have been able to detect it as food. Many animals have evolved sensory systems that will only recognize and locate food in the presence of certain substances or cues (Brusca \& Brusca 2003). Therefore, to properly investigate why this group of species did not eat, detailed information of the feeding biology for species level would be needed. Interestingly, the majority of these species were either carnivorous or omnivorous, which are thought to include many kinds of eggs in their diets (Orians \& Janzen 1974). Take for example the nemertean L. lacteus. Although it 
belongs to a macrophagous genus that captures its prey by rapidly everting the proboscis and secreting substances that paralyse it (Thiel \& Reise 1993), there are no previous studies on its feeding ecology. Yet, its related nemertean Riseriellus occultus is known to feed on gastropods and bivalves (Beckers et al., 2015). Thus, the behaviour of L. lacteus in these experiments would not be consistent with the probable natural feeding behaviour of the species. Whereas the negatives results obtained with Upogebia sp. were in accordance with its known feeding biology; a detritivorous animal that generates water currents and feeds on suspended material (Dworschak 1987).

\subsection{The ambiguous case of the molluscan species}

In our experiments, $O$. vulgaris and the gastropods did not show predation on EC (or EWC for the gastropod S. haemastoma). However, it should be noted that these results pertain only to one observation and so should be regarded with caution and considered primarily as case studies to further explore. This is especially evident for the species $H$. trunculus and $S$. granulata undulata which yielded negative results using our experimental design but that could produce a different outcome for experiments with either a longer starvation period or longer exposure time to eggs, since these species showed predation when the exposition time to EC was longer. Besides, H. trunculus is believed to be an opportunistic predator that may also scavenge, that thrives in ultraoligotrophic marine waters off the coast of Israel, where food is limited (Peharda \& Morton 2006) and in aquarium can survive up to months without feeding (Sawyer et al. 2009). Thus, a longer experiment might be more suitable to investigate feeding traits of species like this one.

\subsection{The feeding biology of potential predators of Sepia officinalis eggs}

Traditionally, sea urchins are considered predominantly herbivores but they can consume a wide variety of animal protein and for many, an omnivorous or unambiguously carnivorous diet has been reported (Crook \& Davoren 2016, Jangoux \& Lawrence 1982). Even though $P$. lividus appears to have a reduced ability to assimilate animal material when compared with other sea urchins like Arbacia lixula (Wangensteen et al. 2011), it showed predation on EC in the laboratory experiments. This was also the case for the other two echinoids tested; Echinus melo and Cidaris sp. Thus, the egg capsule did not appear to oppose as much resistance for echinoids. To feed, this group depends mainly on the Aristotle's lantern, a complex masticatory 
structure located inside the mouth that bears several calcareous protractible teeth (Brusca \& Brusca 2003). This tough structure is also capable of a variety of movements of the teeth, including protraction, retraction and grasping and many species are able to protrude the teeth at different angles (Brusca \& Brusca 2003). Feeding on other marine benthic egg masses by sea urchins has been previously reported for Strongylocentrotus droebachiensis who is thought to be an important predator of egg masses of the whelk Buccinum undatum and an important source of mortality of other gastropod embryos (Dumont et al. 2008). Therefore, S. officinalis eggs could be part of the diet of littoral sea urchins with more carnivorous or omnivorous feeding habits. Aside from sea urchins, EC were consumed by predators with either carnivorous or omnivorous diets; the starfish A. aranciacus, known to be a voracious predator with a carnivorous diet (Baeta \& Ramón 2013) and the two crabs, Cancer pagurus and Dardanus arrosor. Both these crabs are active predators although hermit crabs are generally omnivorous and display a range of feeding strategies (Hazzlet 1981). For instance, the congeneric of $D$. arrosor, D. setifer is known to be highly mobile and have an opportunistic predatory and scavenging behaviour, using its large chelae to grasp and break up its food or prey (Kunze \& Anderson 1979). On the other hand, C. pagurus is considered a more sluggish predator that predominantly ambushes epifaunal prey without distancing itself much from its refuge or its proximities (Lawton 1989). Another relevant feature is the fact that $C$. pagurus also exhibits a high degree of specialization on hard-shelled prey and possesses claws more powerful than omnivorous crabs (Yamada \& Boulding 1998). In contrast, Carcinus maenas, a very active and voracious predator but with an omnivorous diet (Chaves et al. 2010, Ropes 1968), has relatively smaller, thinner chelae with less crushing strength (Moody \& Steneck 1993). Interestingly, this is one of the species that consumed EWC but were not able to prey on EC. The other decapod that consumed EWC and failed to prey on EC was $N$. norvegicus, also a predator with scavenging activity and a generalist diet (Cristo \& Cartes 1998). This species captures its prey or food material grasping it with the chelipeds and walking legs (Bell et al. 2013) which may not have the strength and dexterity to rupture the egg capsule but that would allow them to feed on eggs of S. officinalis if these are protected only by the chorion membrane. The other species that consumed EWC and did not feed on EC was the anemone $C$. parasitica, which generally lives attached to gastropod shells inhabited by hermit crabs (Ross \& Sutton 1961). Although generally a suspension feeder, it is characterized for having a very omnivorous generalist diet because it also preys on a 
wide spectrum of organisms living in the sediment (Chintiroglou \& Koukouras 1991). In particular, this species is known to twist its body so that the entire expanded oral disc becomes almost parallel to the substratum allowing its tentacles to swipe the substratum, but it also eats food particles of large prey captured and tore into pieces by the hermit crab that come into contact with its tentacles (Chintiroglou \& Koukouras 1991). On the other hand, predatory behaviour by $C$. parasitica, and other sea anemones, has also been documented under determined environmental conditions (Riedel et al. 2008).

Moreover, the results of the echinoderms A. aranciacus and P. lividus are noticeable: although they consumed EC, they did not consume EWC in the experimental conditions. These results, however, seem more likely to be an anomaly or due to individual variability rather than indicate that the chorion membrane was acting as an effective protective barrier since other individuals of these species were able to break the barrier posed by the egg capsule when offered EC. On the other hand, all species that ingested EC and/or EWC also consumed OO, suggesting that OO had an insufficient physical barrier to protect the food material from predation.

\subsection{Egg capsule and chorion membrane protective features}

Performing MCA analyses with different combinations of the biological variables allowed us to identify the method of food capture (i.e. capture tools) as the biological trait that appeared to best explain the results of the feeding laboratory experiments. Given that whether or not eggs of S. officinalis were eaten appeared to be determined by a mechanical factor, this finding seems to highlight the importance of having the tools capable of surpassing the resistance of a mechanical barrier.

The $S$. officinalis embryo develops surrounded by different layers that shield it from the surrounding environment (Boletzky 1986, Lacoue-Labarthe et al. 2016). The most important barrier against environmental damages is the egg capsule (Boletzky 1998). Its resistance properties are evidenced for several of the species tested here as potential predators, especially for those, like $C$. maenas, that showed an intention to prey on eggs but did not surpass the egg capsule. Nonetheless, these protective properties were not sufficient for species with powerful capture tools, like C. pagurus or the echinoids, which successfully ruptured the egg capsule. On the other hand, egg capsules also undergo changes in close relation to the metabolism of the embryo (Boletzky 1998). For 
instance, towards the end of the embryological development the egg capsule becomes thinner and more transparent (Wolf et al. 1985, Cornet et al. 2015). Consequently, predation on eggs at different stages of development might also differ. However, this aspect was not evaluated in the present study. Furthermore, even if an animal fails to prey on S. officinalis eggs, damages to the capsule may be made in the process of inspection that might be harmful to the viability of the embryo. Even a small hole may constitute a point of entry to a variety of microfauna and hinder the survival of the embryo. Also, it might make eggs more likely to detach from the egg masses and from its substrate leading to, for example, scenarios of reduced oxygen diffusion due to the egg resting and rolling over the sediment and/or surface abrasion of the capsule, which would diminish embryo survival. Thus, manipulation of these eggs by benthic animals, even without predation, might also contribute to egg mortality.

The chorion membrane is the chronological primary egg cover and the primary egg protection (Boletzky 1986, Boletzky 2010). However, by itself this structure is insufficient for effective protection of the embryo from the outside environment (Boletzky 2010). This is supported in our laboratory results since species that appeared to be attracted to this type of food were able to feed on eggs only protected by the expanded chorion membrane (EWC). As far as we know, this is a membrane that also acts as a passive barrier for many molecules (Bonnaud et al. 2013, Lacoue-Labarthe et al. 2016). Thus, it could also govern the diffusion of attractive odours that might be detected by other putative predators. Moreover, it is a structure that hinders the manipulation of the egg, evidenced by the scenario observed for individuals of $N$. norvegicus where the EWC had a tendency to swing and bounce with the movement of the chelipeds.

The structural protection of $S$. officinalis egg masses might be coupled with chemical defence mechanisms, which should not be overlooked either. This potential chemical protection might be provided by ink, living bacteria inside the egg capsule and antifouling properties and antimicrobial properties of egg capsule proteins (Cornet et al. 2015). In particular, ink has been suggested to function as a chemical deterrent (Derby 2014) and it might provide a repulsive smell to ward off predators when imbedded in the egg capsule (Cornet et al. 2015). 


\section{CONCLUSION}

This study has showed that predation on egg masses of the European cuttlefish Sepia officinalis by benthic marine invertebrates may be possible. Under laboratory conditions, 22 different invertebrate species of 6 different phyla and with diverse feeding habits were tested as potential predators of S. officinalis eggs, revealing that these were preyed on mainly by crabs, sea urchins and a starfish (Astropecten aranciacus). The laboratory results are not enough to support the concept that species that showed predation on eggs with capsule (EC) should be considered a predator of $S$. officinalis eggs, even more so if we bear in mind that in the field other prey will be available for these predators. Nonetheless, it can be argued that cuttlefish eggs could be part of their diet; at least for certain periods of time since changes in prey availability or environmental conditions may induce shifts in predator diets (Pickering \& Quijón 2011). Regarding the egg capsule of S. officinalis, evidence of its mechanical protective functions is presented. The ability of the chorion membrane to act as a physical barrier and hinder the manipulation by invertebrate animals of a S. officinalis egg protected only by this membrane was also explored. Moreover, the results obtained suggest that egg masses of $S$. officinalis may be vulnerable to some benthic invertebrate predators and that eggs rely on passive structural characteristics to avoid predation, though chemical properties and putative deterrents also have to be considered and should be investigated further.

\section{REFERENCES}

Baeta, M. \& Ramón, M. (2013). Feeding ecology of three species of Astropecten (Asteroidea) coexisting on shallow sandy bottoms of the northwestern Mediterranean Sea. Marine biology 160(11): 2781-2795.

Beckers, P.; Bartolomeaus, T. \& Dörhen, J. v. (2015). Observations and experiments on the biology and life history of Riseriellus occultus (Heteronemertea: Lineidae). Zoological Science 32(6): 531-546.

Bell, M.; Tuck, I. \& Dobby, H. (2013). Nephrops species. In: Phillips, B. (ed.) Lobsters: Biology, Management, Aquaculture \& Fisheries, Second Edition. Wiley-Blackwell Publishing, Oxford, pp. 357-413. 
Bigatti, G.; Giraud-Billoud, M.; Vega, I. A.; Penchaszadeh, P. E. \& Castro-Vazquez, A. (2010). The calcareous egg capsule of the Patagonian neogastropod Odontocymbiola magellanica: morphology, secretion and mineralogy. Journal of Molluscan Studies 76(3): 279-288.

Biggs, J. \& Epel, D. (1991). Egg capsule sheath of Loligo opalescens Berry: structure and association with bacteria. Journal of Experimental Zoology 259(2): 263-267.

Blanc, A. \& Daguzan, J. (1999). Young cuttlefish Sepia officinalis (Mollusca: Sepiidae) in the Morbihan Bay (south Brittany, France): accessory prey of predators. Journal of the Marine Biological Association of the UK 79(06): 1133-1134.

Bloor, I.S.; Attrill, M.J. \& Jackson, E.L. (2013). A review of the factors influencing spawning, early life stage survival and recruitment variability in the common cuttlefish (Sepia officinalis). Advances in Marine Biology 65: 1-65.

Boletzky, S.V. (1983). Sepia officinalis. In: Boyle, P.R. (ed.) Cephalopod Life Cycles, Vol. 1. Academic Press, London, pp. 31-52.

Boletzky, S.V. (1986). Reproductive strategies in cephalopods: variation and flexibility of life-history patterns. Advances in Invertebrate Reproduction 4: 379-389.

Boletzky, S.V. (1998). Cephalopod eggs and egg masses. Oceanography and Marine Biology, 36: 341-372.

Boletzky, S.V. (2003). Biology of early life stages in cephalopod molluscs. Advances in Marine Biology 44: 144-204.

Boletzky, S.V. (2010). The 'yolk organ' of cephalopod embryos: on transient functions from crawling substratum to provisional knapsack. Ferrantia 59: 14-21.

Boletzky, S.V.; Andouche, A. \& Bonnaud-Ponticelli, L. (2016). A developmental table of embryogenesis in Sepia officinalis. Vie et Milieu 66(1): 11-23.

Bonnaud, L.; Franko, D.; Vouillot, L. \& Bouteau, F. (2013). A study of the electrical polarization of Sepia officinalis yolk envelope, a role for $\mathrm{Na}+\mathrm{K}+-\mathrm{ATPases}$ in osmoregulation? Communicative \& Integrative Biology 6: e26035. 
Brusca, R.C. \& Brusca, G.J. (2003) Invertebrates, Second Edition. Sinauer Associates, Sunderland, Massachusetts.

Chaves, M.L.; Horta, M.S.; Chainho, P.; Costa, M.J. \& Costa, J.L. (2010). New additions to the feeding ecology of Carcinus maenas (L., 1758) in a South-western Europe estuary (Portugal). Cahiers de Biologie Marine 51: 229-238.

Chintiroglou, C. \& Koukouras, A. (1991). Observations on the feedings habits of Calliactis parasitica (Couch, 1842), Anthozoa, Cnidaria. Oceanologica Acta 14(4): 389-396.

Corner, B.D. \& Moore, H.T. (1980). Field observations on the reproductive behaviour of Sepia latimanus. Micronesica 16(2): 235-260.

Cornet, V.; Henry, J.; Goux, D.; Duval, E.; Bernay, B.; Le Corguillé, G.; Corre, E. \& Zatylny-Gaudin, C. (2015). How Egg Case Proteins Can Protect Cuttlefish Offspring? PloS one 10(7): e0132836.

Cristo, M. \& Cartes, J.E. (1998). A comparative study of the feeding ecology of Nephrops norvegicus L. (Decapoda: Nephropidae) in the bathyal Mediterranean and the adjacent Atlantic. Scientia Marina 62(Supl.1): 81-90.

Cronin, E.R. \& Seymour, R.S. (2000). Respiration of the eggs of the giant cuttlefish Sepia apama. Marine Biology 136(5): 863-870.

Crook, K.A. \& Davoren, G.K. (2016). Influence of spawning capelin Mallotus villosus on the distribution of green sea urchins Strongylocentrotus droebachiensis on the northeast Newfoundland coast. Marine Ecology Progress Series 549: 125-135.

Cyran, N.; Staedler, Y.; Schönenberger, J.; Klepal, W. \& Byern, J.V. (2013). Hatching glands in cephalopods - A comparative study. Zoologischer Anzeiger 253(1): 66-82.

Derby, C.D. (2014). Cephalopod ink: production, chemistry, functions and applications. Marine drugs 12(5): 2700-2730.

Dumont, C.P.; Roy, J.S. \& Himmelman, J.H. (2008). Predation by the sea urchin Strongylocentrotus droebachiensis on capsular egg masses of the whelk Buccinum undatum. Journal of the Marine Biological Association of the United Kingdom 88(5): 1025-1031. 
Dworschak, P.C. (1987). Feeding behaviour of Upogebia pusilla and Callianassa tyrrhena (Crustacea, Decapoda, Thalassinidea). Investigación Pesquera 51(Supl.1): 421429.

Guerra, A. (2006). Ecology of Sepia officinalis. Vie et Milieu 56(2): 97-107.

Guerra, A. \& González, J. (2011). First record of predation by a tompot blenny on the common cuttlefish Sepia officinalis eggs. Vie et Milieu 61(1): 45-48.

Guerra, Á.; Hernández-Urcera, J.; Garci, M. E.; Sestelo, M.; Regueira, M.; Gilcoto, M.; \& González, A.F. (2016). Spawning habitat selection by the common cuttlefish Sepia officinalis in the Cíes Islands (Northwest Spain). Fisheries Research 183: 44-54.

Gutsal, D.K. (1989). Underwater observations on distribution and behavior of cuttlefish Sepia pharaonis in the western Arabian Sea. Biolgiya morya (Soviet Journal of Marine Biology) 1: 48-55.

Hazlett, B.A. (1981). The behavioral ecology of hermit crabs. Annual Review of Ecology and Systematics 12: 1-22.

Jangoux, M. \& Lawrence, J.M. (1982). Echinoderm nutrition. CRC Press, Balkema, Rotterdam.

Kunze, J. \& Anderson, D.T. (1979). Functional morphology of the mouthparts and gastric mill in the hermit crabs Clibanarius taeniatus (Milne Edwards), Clibanarius virescens (Krauss), Paguristes squamosus McCulloch and Dardanus setifer (MilneEdwards) (Anomura: Paguridae). Marine and Freshwater Research 30(5): 683-722.

Kuris, A.M.; Blau, S.F.; Paul, A.J.; Shields, J. D. \& Wickham, D.E. (1991). Infestation by brood symbionts and their impact on egg mortality of the red king crab, Paralithodes camtschatica, in Alaska: geographic and temporal variation. Canadian Journal of Fisheries and Aquatic sciences 48: 559-568.

Lacoue-Labarthe, T.; Le Pabic, C. \& Bustamante, P. (2016). Ecotoxicology of early-life stages in the common cuttlefish Sepia officinalis: review and perspectives. Vie et Milieu 66(1): 65-79. 
Laptikhovsky, V.; Salman, A.; Önsoy, B. \& Katagan, T.(2003). Fecundity of the common cuttlefish, Sepia officinalis L. (Cephalopoda, Sepiidae): a new look at an old problem*. Scientia Marina 67(3): 279-284.

Lawton, P. (1989). Predatory interaction between the brachyuran crab Cancer pagurus and decapod crustacean prey. Marine Ecology Progress Series. 52: 169-179.

Lê, S.; Josse, J.; \& Husson, F. (2008). FactoMineR: an R package for multivariate analysis. Journal of Statistical Software 25(1): 1-18.

Lemaire, J. (1970). Table de développement embryonnaire de Sepia officinalis L. (Mollusque Céphalopode). Bulletin de la Société Zoologique de France 95: 773-782.

Matozzo, V.; Conenna, I.; Riedl, V.M.; Marin, M.G.; Marčeta, T. \& Mazzoldi, C. (2015). A first survey on the biochemical composition of egg yolk and lysozyme-like activity of egg envelopment in the cuttlefish Sepia officinalis from the Northern Adriatic Sea (Italy). Fish \& Shellfish Immunology 45: 528-533.

Melli, V.; Riginella, E.; Nalon, M. \& Mazzoldi, C. (2014). From Trap to Nursery. Mitigating the Impact of an Artisanal Fishery on Cuttlefish Offspring. PLoS ONE 9(2): e90542.

Moody, K.E. \& Steneck, R.S. (1993). Mechanisms of predation among large decapod crustaceans of the Gulf of Maine coast: functional vs. phylogenetic patterns. Journal of Experimental Marine Biology and Ecology 168: 111-124.

Orians, G.H. \& Janzen, D.H. (1974). Why are embryos so tasty? The American Naturalist 108(963): 581-592.

Peharda, M. \& Morton, B. (2006). Experimental prey species preferences of Hexaplex trunculus (Gastropoda: Muricidae) and predator-prey interactions with the Black mussel Mytilus galloprovincialis (Bivalvia: Mytilidae). Marine Biology 148(5): 10111019.

Perron, F.E. (1981). The partitioning of reproductive energy between ova and protective capsules in marine gastropods of the genus Conus. The American Naturalist 118(1): 110-118. 
Pickering, T. \& Quijón, P.A. (2011). Potential effects of a non-indigenous predator in its expanded range: assessing green crab, Carcinus maenas, prey preference in a productive coastal area of Atlantic Canada. Marine Biology 158(9): 2065-2078.

Prota, G.; Ortonne, J.P.; Voulot, C.; Khatchadourian, C.; Nardi, G. \& Palumbo, A. (1981). Occurrence and properties of tyrosinase in the ejected ink of cephalopods. Comparative Biochemistry and Physiology Part B: Comparative Biochemistry 68(3): 415-419.

Riedel, B.; Stachowitsch, M. \& Zuschin, M. (2008). Sea anemones and brittle stars: unexpected predatory interactions during induced in situ oxygen crises. Marine Biology 153(6): 1075-1085.

Rocha, F.; Guerra, A. \& González, A.F. (2001). A review of reproductive strategies in cephalopods. Biological Reviews 76: 291-304.

Roche, A.; Maggioni, M. \& Narvarte, M. (2011). Predation on egg capsules of Zidona dufresnei (Volutidae): ecological implications. Marine Biology 158(12): 2787-2793.

Ropes, J.W. (1968). The feeding habits of the green crab, Carcinus maenas (L.). Fishery Bulletin 67(2): 183-203.

Ross, D.M. \& Sutton, L. (1961). The association between the hermit crab Dardanus arrosor (Herbst) and the sea anemone Calliactis parasitica (Couch). Proceedings of the Royal Society of London. Series B: Biological Sciences 155(959): 282-291.

Sawyer, J.A.; Zuschin, M.; Riedel, B. \& Stachowitsch, M. (2009). Predator-prey interactions from in situ time-lapse observations of a sublittoral mussel bed in the Gulf of Trieste (Northern Adriatic). Journal of Experimental Marine Biology and Ecology 371: 10-19.

Sherrard, K.M. (2000). Cuttlebone morphology limits habitat depth in eleven species of Sepia (Cephalopoda: Sepiidae). Biological Bulletin 198: 404-414.

Sykes, A.V.; Almansa, E.; Lorenzo, A. \& Andrade, J.P. (2009). Lipid characterization of both wild and cultured eggs of cuttlefish (Sepia officinalis L.) throughout the embryonic development. Aquaculture Nutrition 15: 38-53. 
Sykes, A.V.; Domingues, P. \& Andrade, J. P. (2014). Sepia officinalis. In: Iglesias, J.; Fuentes, L. \& Villanueva, R. (eds.) Cephalopod Culture. Springer, Netherlands, pp. 175-204.

Teletchea, F.; Fostier, A.; Kamler, E.; Gardeur, J.N.; Le Bail, P.Y.; Jalabert, B. \& Fontaine, P. (2009). Comparative analysis of reproductive traits in 65 freshwater fish species: application to the domestication of new fish species. Reviews in Fish Biology and Fisheries 19(4): 403-430.

Thiel, M. \& Reise, K. (1993). Interaction of nemertines and their prey on tidal flats. Netherlands Journal of Sea Research 31(2): 163-172.

Wangensteen, O.S.; Turon, X.; García-Cisneros, A.; Recasens, M.; Romero, J. \& Palacín, C. (2011). A wolf in sheep's clothing: carnivory in dominant sea urchins in the Mediterranean. Marine Ecology Progress Series 441: 117-128.

Wolf, G.; Verheyen, E.; Vlaeminck, A.; Lemaire, J. \& Decleir, W. (1985). Respiration of Sepia officinalis during embryonic and early juvenile life. Marine Biology 90: 3539.

Yamada, S.B. \& Boulding, E.G. (1998). Claw morphology, prey size selection and foraging efficiency in generalist and specialist shell-breaking crabs. Journal of Experimental Marine Biology and Ecology 220: 191-211.

Zatylny, C.; Gagnon, J.; Boucaud-Camou, E. \& Henry, J. (2000). ILME: a waterborne pheromonal peptide released by the eggs of Sepia officinalis. Biochemical and Biophysical Research Communications 275(1): 217-222.

Zatylny, C.; Marvin, L.; Gagnon, J. \& Henry, J. (2002). Fertilization in Sepia officinalis: the first mollusk sperm-attracting peptide. Biochemical and Biophysical Research Communications 296(5): 1186-1193. 


\section{APPENDIX}

A

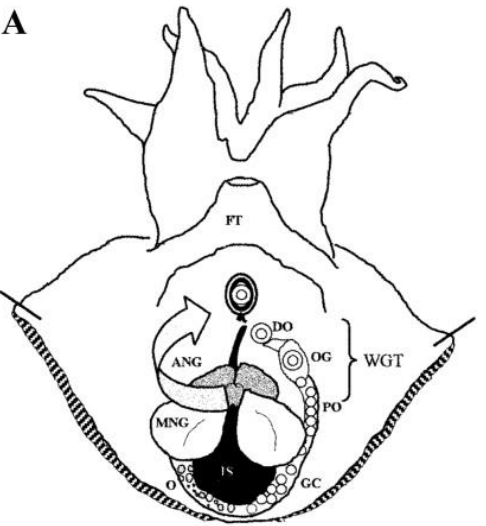

4. Embedded oocyte with nidamental jelly and ink

(2) 3. Oocyte with first gelatinous envelope

- 2. Mature oocyte

1. Vitellogenic oocyte

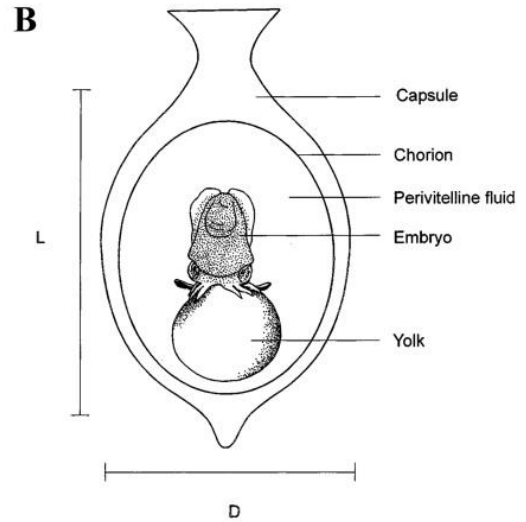

Fig. A1. Schematic drawings of (A) the internal structures and steps of ovulation and enveloping of eggs in a mature Sepia officinalis female from ventral view (taken from Zatylny et al. 2000) and (B) of a Sepia egg (taken from Cronin \& Seymour 2000). (ANG, accessory nidamental glands; D diameter; DO, distal oviduct; FT, funnel tube; GC, genital coelome; IS, ink sac; L external egg length; MNG, main nidamental glands; O, ovary; OG, oviducal gland; PO, proximal oviduct).
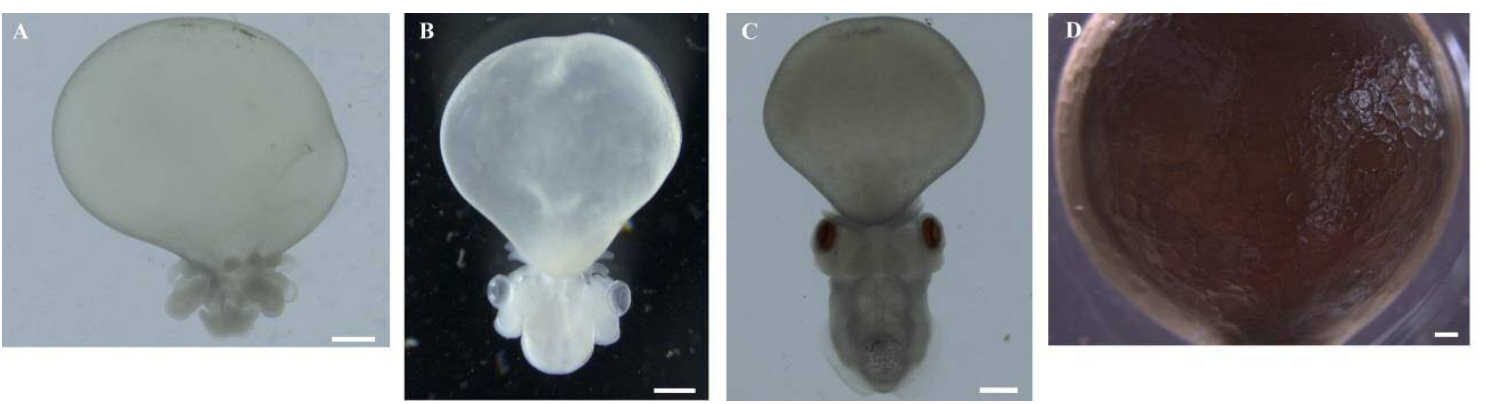

Fig. A2. Sepia officinalis. Embryos at embryological stages (A) 21, (B) 23 and (C) 28 (after Boletzky et al., 2016). (D) Surface of the expanded egg capsule of an egg approaching the end of embryological development. Scale bars: $1 \mathrm{~mm}$. 

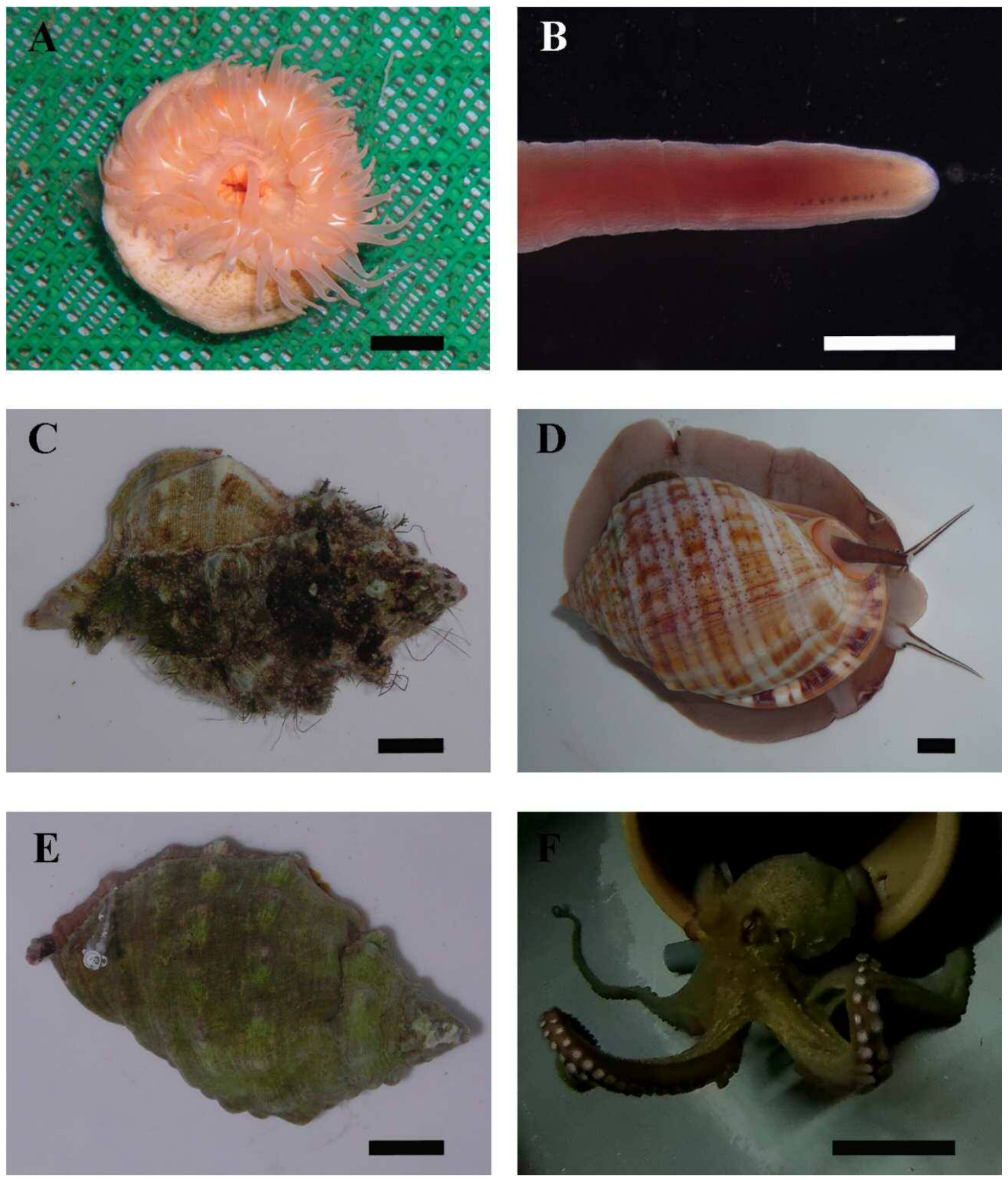

Fig. A3. Species tested as potential predators of Sepia officinalis eggs. (A) Calliactis parasitica. (B) Lineus lacteus. (C) Hexaplex trunculus. (D) Semicassis granulata undulata. (E) Stramonita haemastoma. (F) Octopus vulgaris. (G) Nephtyid. (H) Nereid 1. (I) Nereid 2. (J) Cancer pagurus. (K) Carcinus maenas. (L) Dardanus arrosor. (M) Nephrops norvegicus. (N) Parthenopoides massena. (O) Upogebia sp. (P) Cidaris sp. (Q) Echinus melo. (R) Paracentrotus lividus. (S) Astropecten aranciacus. (T) Coscinasterias tenuispina. (U) Echinaster sepositus. Scale bars: $1 \mathrm{~cm}$, except B and F: $1 \mathrm{~mm}$ and $10 \mathrm{~cm}$ respectively. 

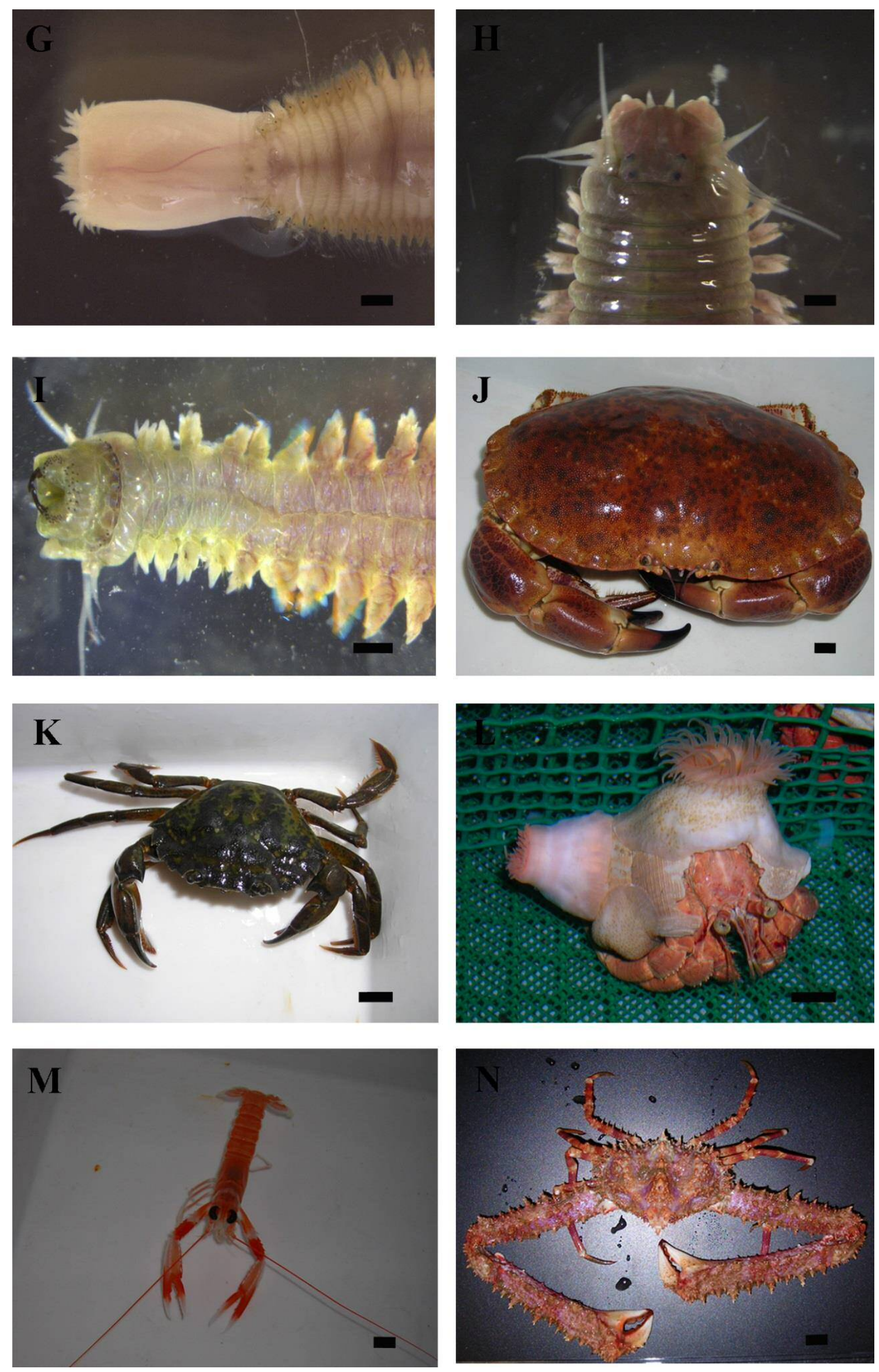

Fig. A3. Continued. 

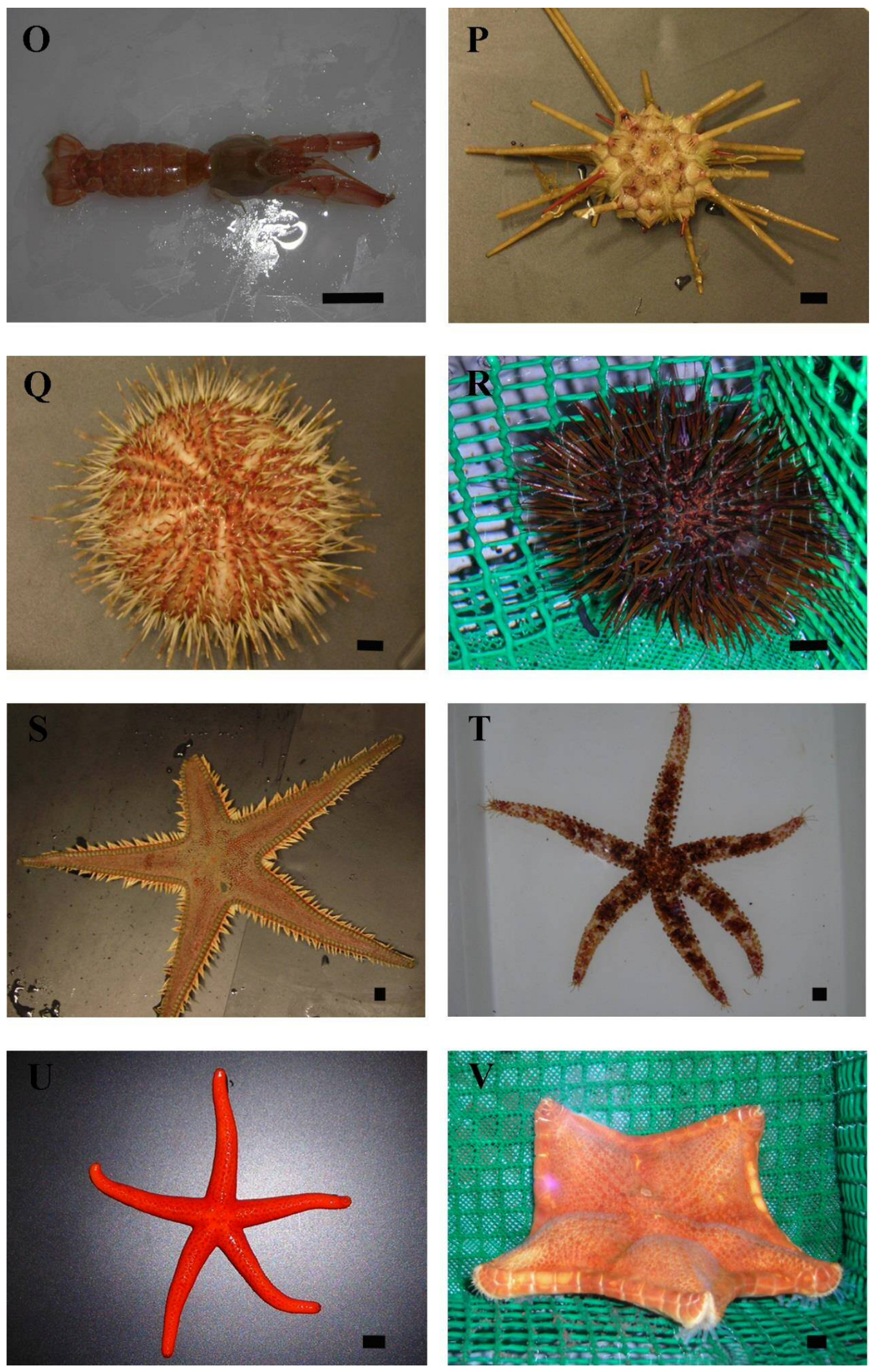

Fig A3. Continued 

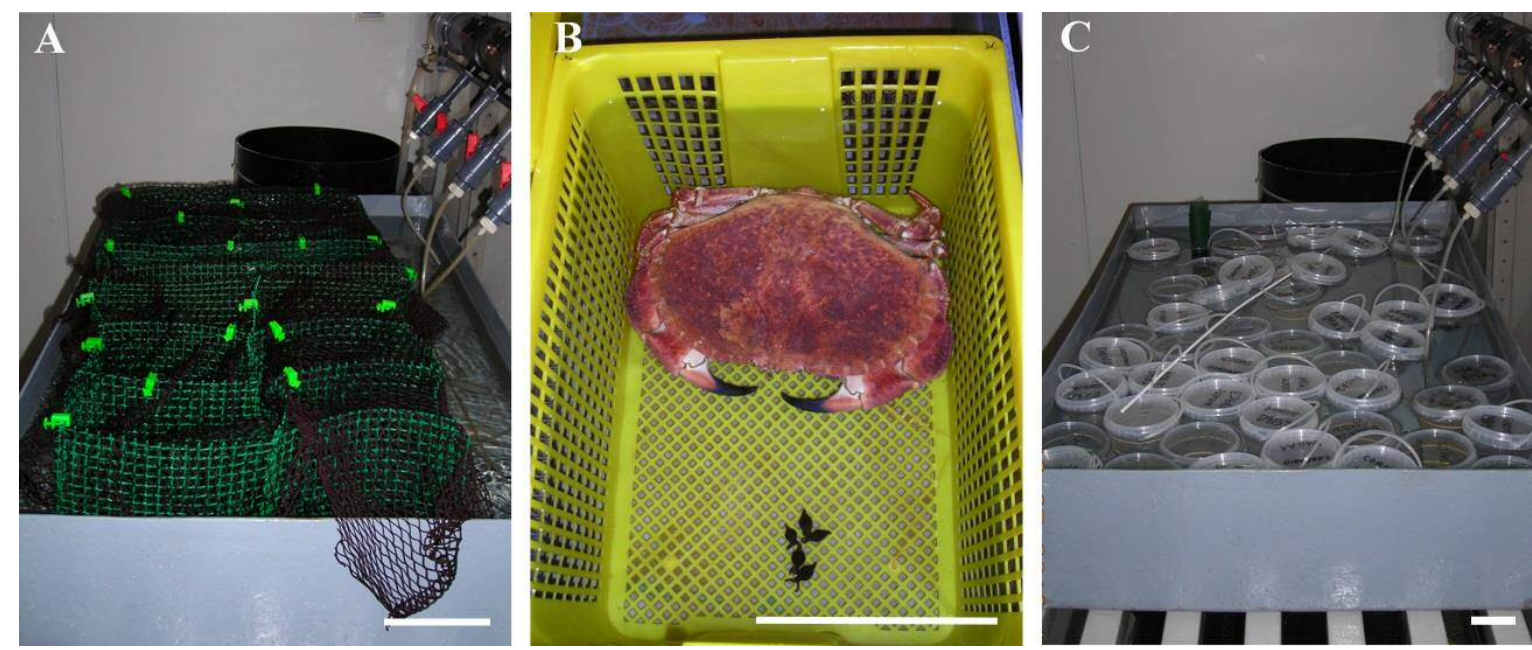

Fig. A4. Experimental set-up using (A) chambered cages of green wire mesh, (B) baskets and (C) plastic containers. Scale bars: $10 \mathrm{~cm}$.

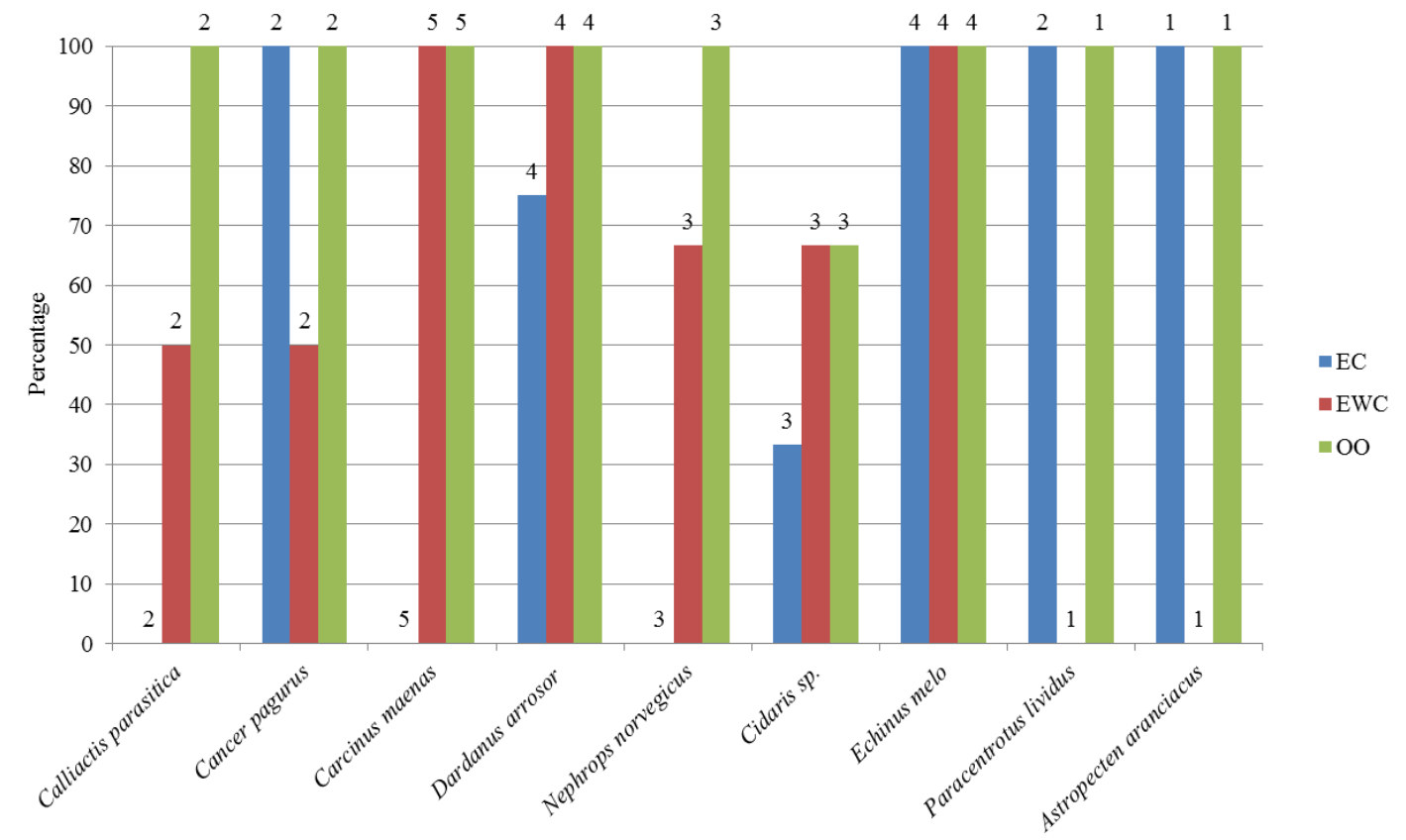

Fig. A5. Percentage of cnidarian, arthropod and echinoderm individuals that consumed EC, EWC or OO per species. Numbers on top of column bars indicate number of individuals tested. (EC, eggs with capsule; EWC, eggs without capsule; OO, oocytes). 

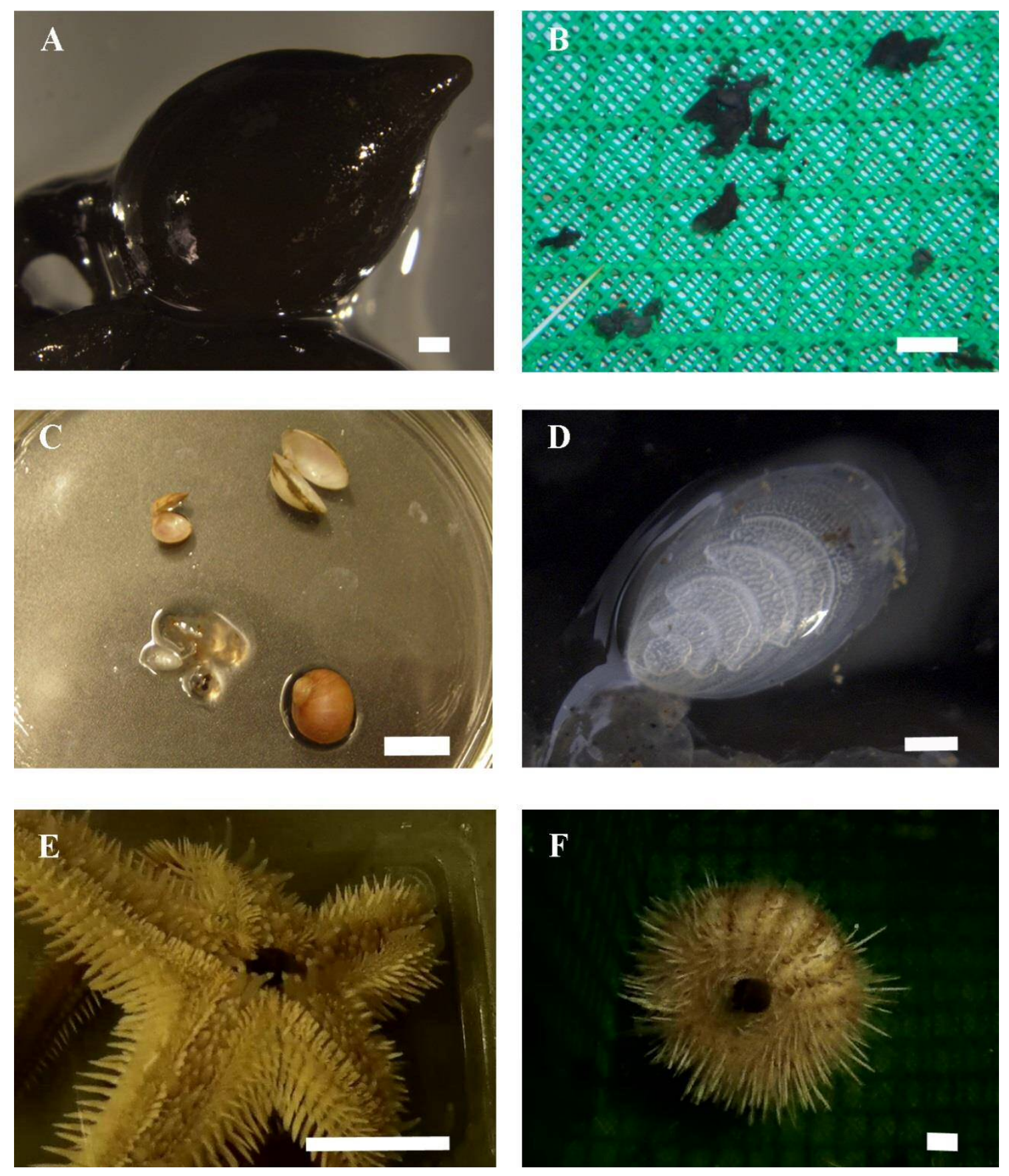

Fig. A6. Different stages of predation of Sepia officinalis eggs. (A) Egg with no marks of predation on the surface of the egg capsule. (B) Remainders of egg capsules after predation of eggs by Dardanus arrosor. (C) Regurgitated shells and cuttlebone by Astropecten aranciacus. (D) Detail of a regurgitated cuttlebone by A. aranciacus. (E) Individual of $A$. aranciacus eating an egg with capsule. (F) Individual of Echinus melo eating and egg with capsule. A and D scale bars: $1 \mathrm{~mm}$. B, C and F scale bars: $1 \mathrm{~cm}$. E scale bar: $10 \mathrm{~cm}$. 
A

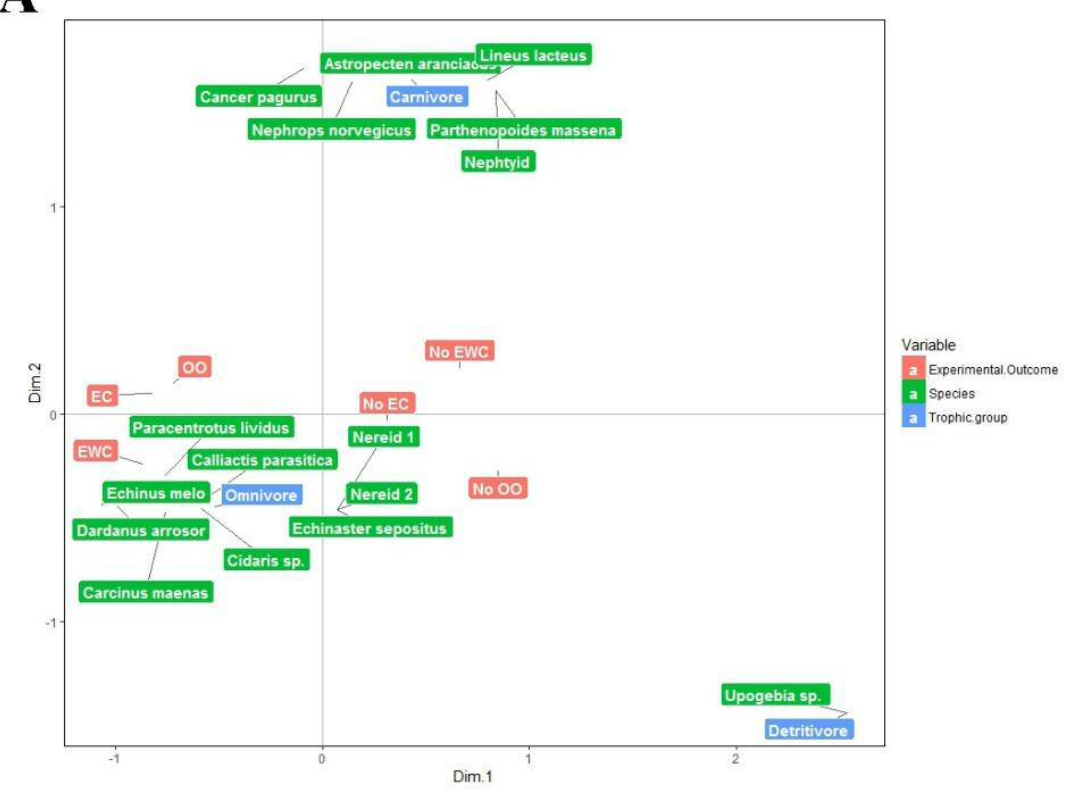

B

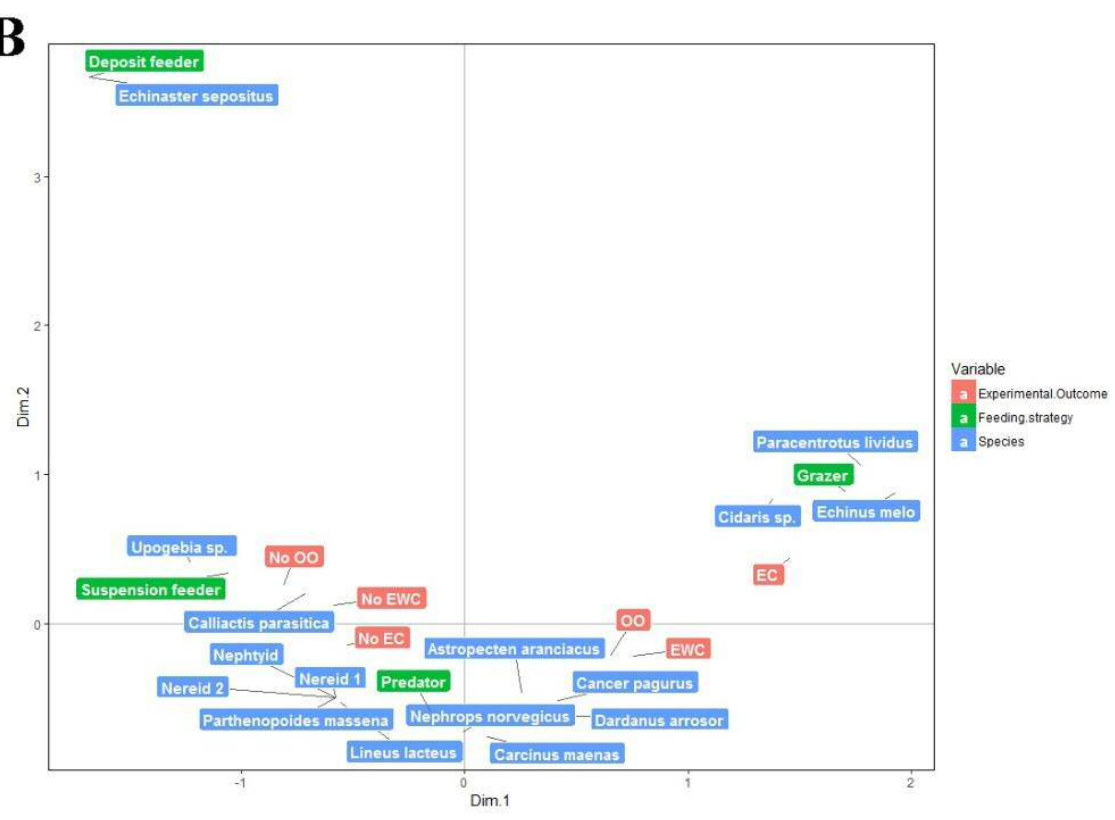

Fig. A7. Multiple Correspondence Analyses of (A) hypothesis 1, (B) hypothesis 2, (C) hypothesis (3), (D) hypothesis 5, (E) hypothesis 6, (F) hypothesis 7, (G) hypothesis 8, (H) hypothesis 9 and (I) hypothesis 10. (EC, eggs with capsule consumed; EWC, eggs without capsule consumed; OO, oocytes consumed; No EC, eggs with capsule not consumed; No EWC, eggs without capsule not consumed, No OO, oocytes not consumed). 

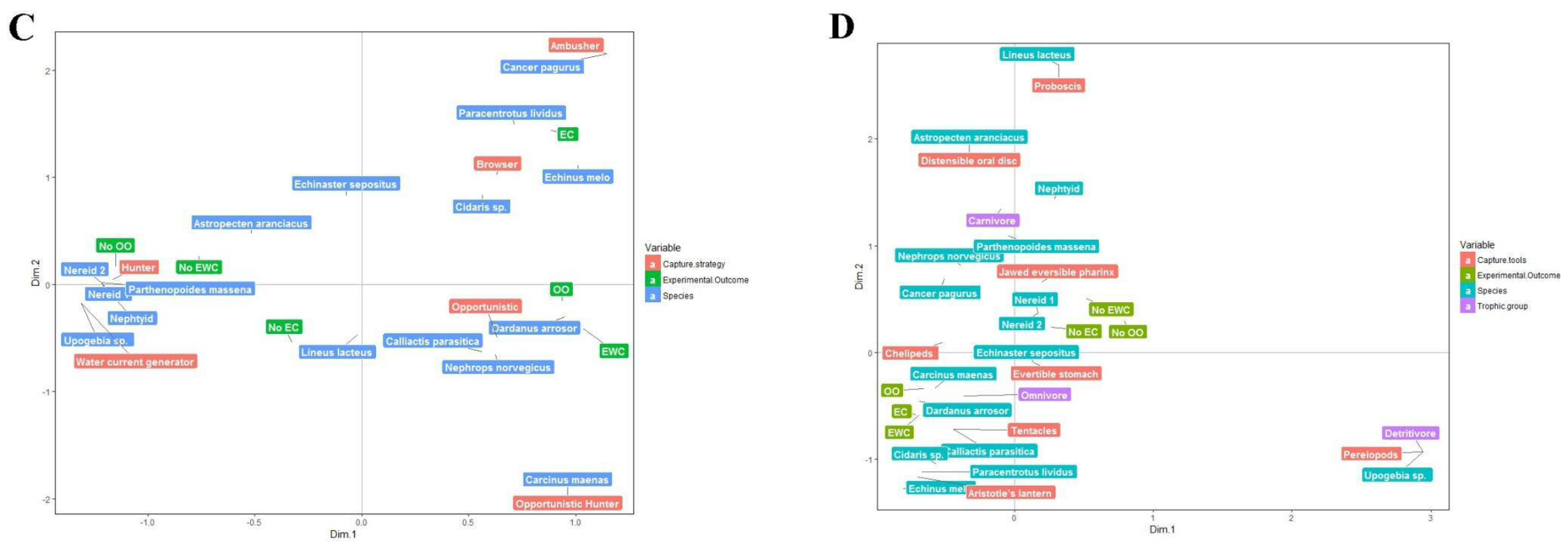

Fig. A7. Continued. 


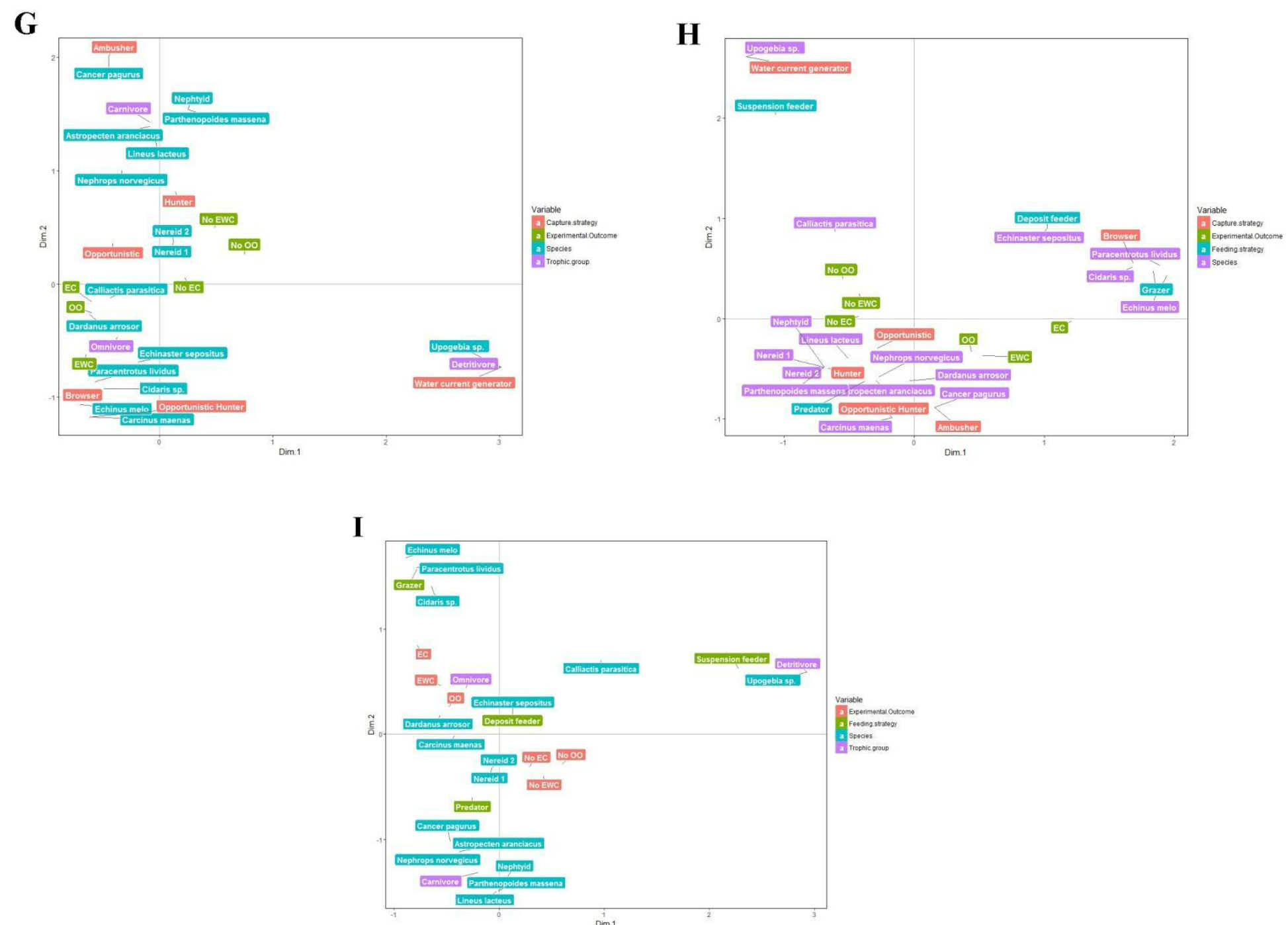

Fig. A7. Continued. 
Table A1. Species tested as potential predators during the present study. All measurements are expressed as mean \pm standard deviation. BS, body size; n, number of individuals tested; N/A, not applicable; WBW, wet body weight.

\section{Common name}

BS (mm)

WBW (g)

\section{Phylum Cnidaria}

Class Anthozoa

Family Hormathiidae

\section{Calliactis parasitica}

\section{Phylum Nemertea}

Class Anopla

Family Lineidae

Lineus lacteus

\section{Phylum Mollusca}

Class Gastropodoa

Family Muricidae

Hexaplex trunculus

Stramonita haemastoma

Banded dye-murex

Red-mouthed rock

shell

$12 \quad 134.4 \pm 31.3$

$0.12 \pm 0.03$

NE Atlantic Ocean

Direct sampling

Origin

Collection method

Family Cassidae

Semicassis granulata undulata

Mediterranean Bonnet
69.4

79.7

44.2

55.1
NW Mediterranean Sea

NW Mediterranean Sea

NW Mediterranean Sea
Trawler fisheries bycatch
Aquarium of Barcelona

Aquarium of Barcelona 
Table A1. Continued.

\begin{tabular}{|c|c|c|c|c|c|c|}
\hline & Common name & $\mathbf{n}$ & BS (mm) & WBW (g) & Origin & Collection method \\
\hline \multicolumn{7}{|l|}{ Class Cephalopoda } \\
\hline \multicolumn{7}{|l|}{ Family Octopodidae } \\
\hline \multicolumn{7}{|l|}{ Phylum Annelida } \\
\hline \multicolumn{7}{|l|}{ Class Polychaeta } \\
\hline Nephtyid & & 9 & $123.0 \pm 41.4$ & $2.3 \pm 0.5$ & NE Atlantic Ocean & Bait market \\
\hline \multicolumn{7}{|l|}{ Family Nereididae } \\
\hline Nereid 1 & & 12 & $210.5 \pm 42.8$ & $5.1 \pm 0.9$ & NE Atlantic Ocean & Bait market \\
\hline Nereid 2 & & 12 & $60.7 \pm 25.2$ & $1.0 \pm 0.3$ & Pacific Ocean & Bait market \\
\hline \multicolumn{7}{|l|}{ Phylum Arthropoda } \\
\hline \multicolumn{7}{|l|}{ Class Malacostraca } \\
\hline \multicolumn{7}{|l|}{ Family Carcinidae } \\
\hline Carcinus maenas & Green crab & 15 & $35.5 \pm 5.8$ & $24.5 \pm 7.9$ & NE Atlantic Ocean & Fish market \\
\hline \multicolumn{7}{|l|}{ Family Diogenidae } \\
\hline Dardanus arrosor & Striated hermit crab & 12 & $10.5 \pm 2.1$ & $54.4 \pm 13.0$ & NW Mediterranean Sea & Trawler fisheries bycatch \\
\hline
\end{tabular}


Table A1. Continued.

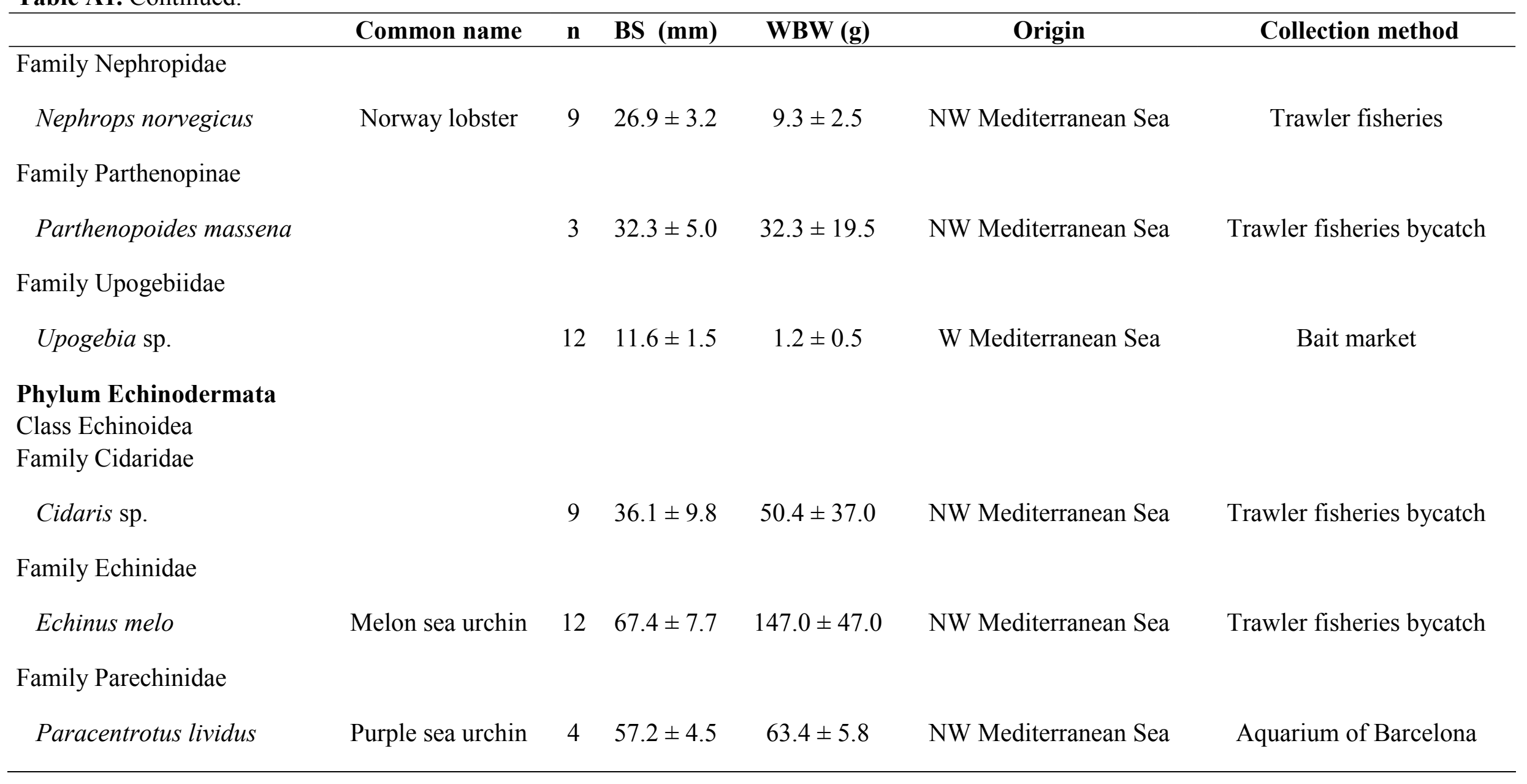


Table A1. Continued.

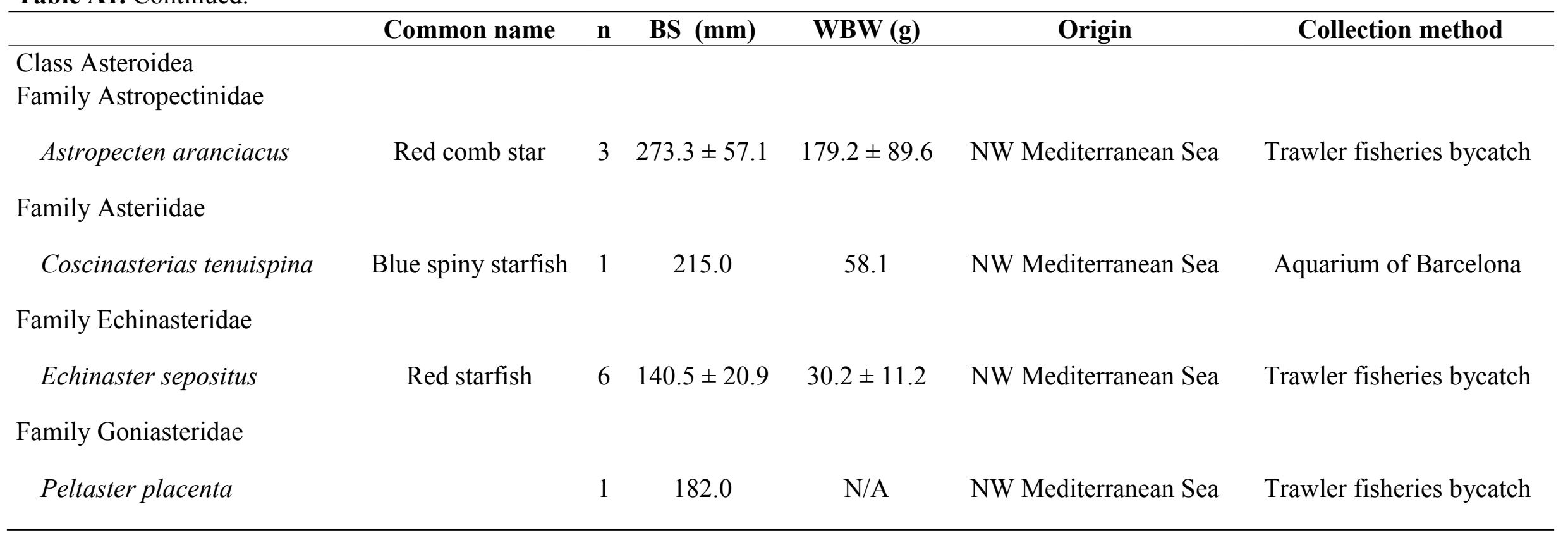


Table A2. Bathymetric distribution overlap of tested potential predator species and spawning bathymetric distribution of Sepia officinalis in the north-east Atlantic and/or Mediterranean Sea, and predominant feeding traits per species. Bathymetric distribution overlap is coded as 'total overlapping' when the spawning depth range of $S$. officinalis is totally covered; 'partial overlapping' when distribution coincides only with a portion of the spawning depth range; and 'bordering' when spawning maximum depth coincides with the minimum depth distribution of the tested species. ABO, accessory boring organ; N/A, not applicable.

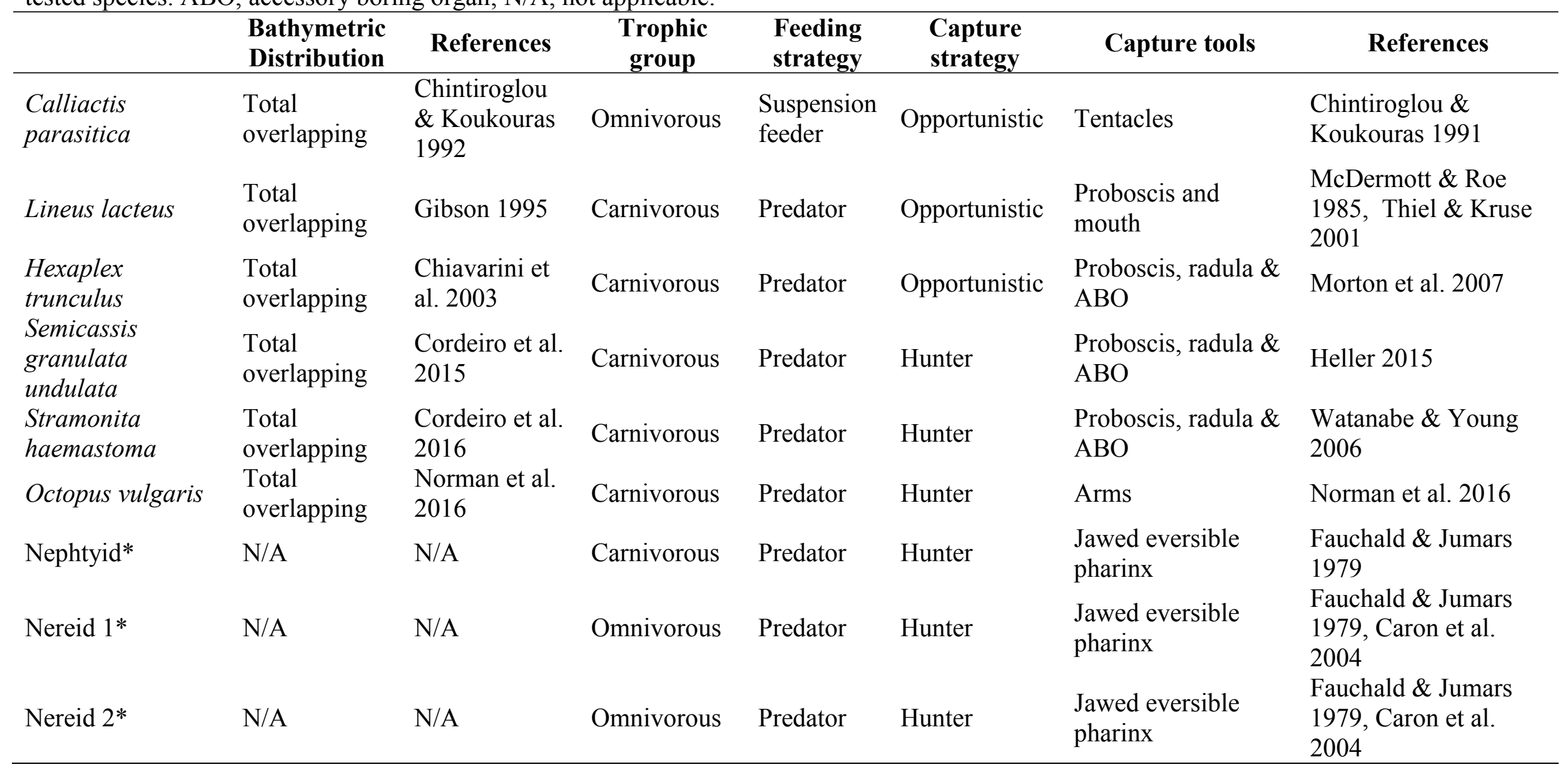


Table A2. Continued.

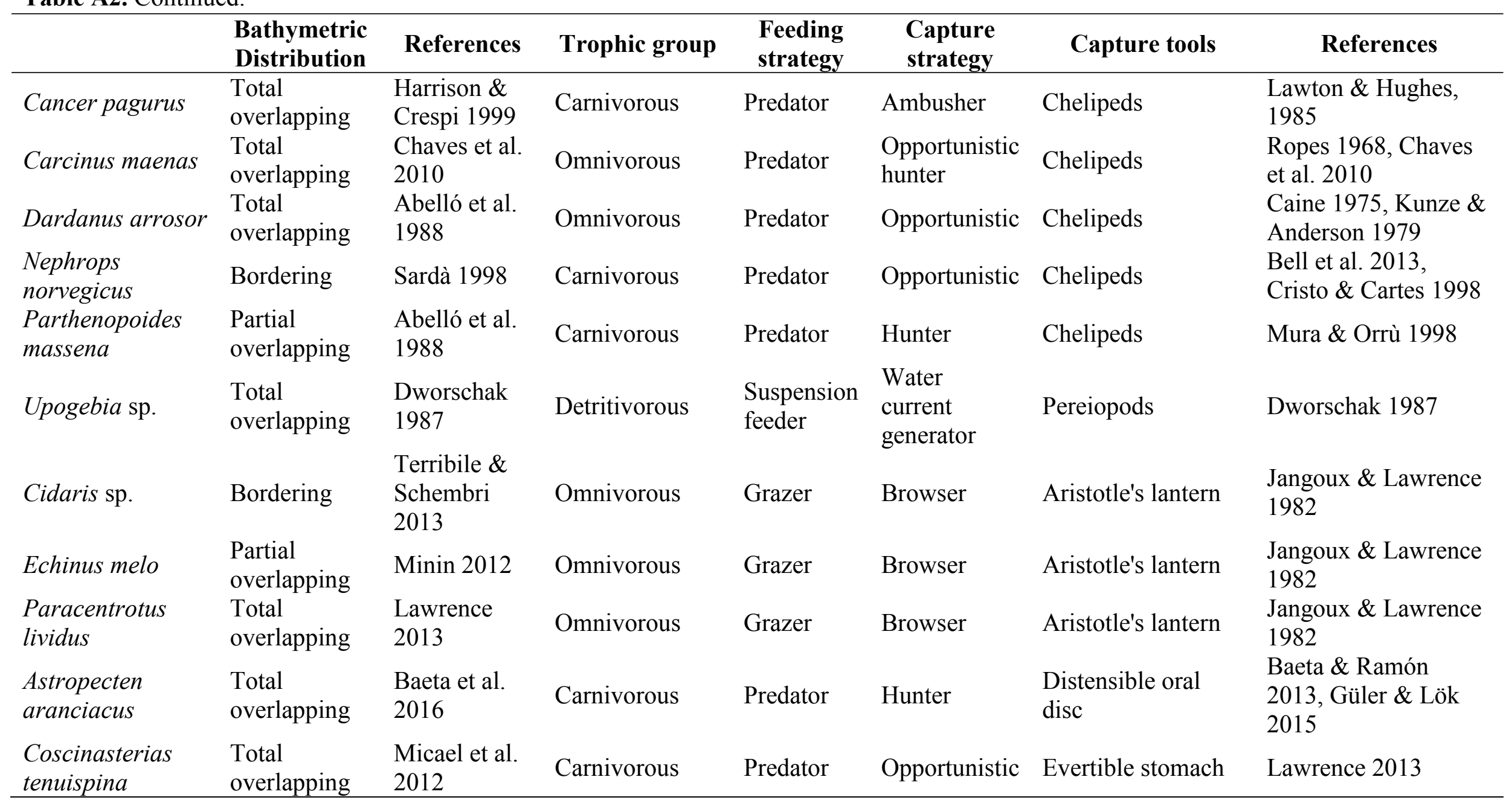


Table A2. Continued.

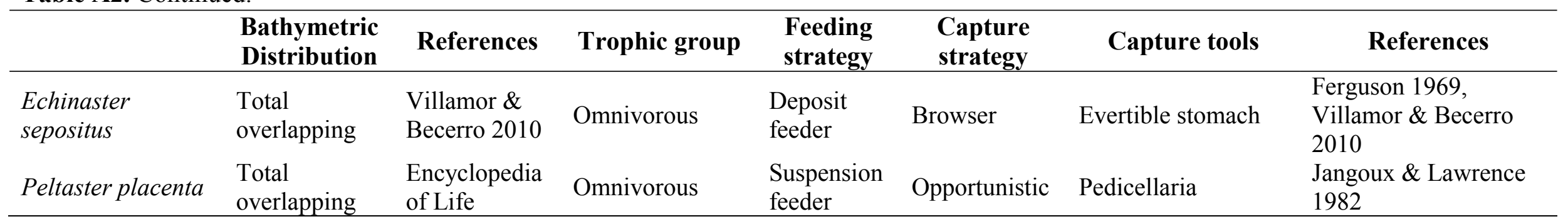

Table A3. Description of the body size measurements used for the potential predator species. *Measurements taken from live animals and could contain certain variability attributed to the continuous contraction and stretching of their body; ** Shield length calculated using a regression function, provided by Pere Abelló (unpublished data) and the length of the first left chela; †Total length measured from the tip of an arm to the tip of the opposite arm.

\begin{tabular}{ll}
\hline Species & Measurement \\
\hline Calliactis parasitica & Pedal disc diameter \\
Lineus lacteus $*$ & Total Length \\
Hexaplex trunculus & Shell length \\
Semicassis granulata undulata & Shell length \\
Stramonita haemastoma & Shell length \\
Octopus vulgaris & Dorsal mantle length \\
Nephtyid* & Total Length \\
\hline
\end{tabular}

Table A3. Continued.

\begin{tabular}{ll}
\hline Species & Measurement \\
\hline Nereid $1^{*}$ & Total Length \\
Nereid $2^{*}$ & Total Length \\
Cancer pagurus & Carapace length \\
Carcinus maenas & Carapace length \\
Dardanus arrosor $* *$ & Shield length \\
Nephrops norvegicus & Carapace length \\
Parthenopoides massena & Carapace length \\
Upogebia sp. & Carapace length \\
Cidaris sp. & Oral diameter \\
Echinus melo & Oral diameter \\
Paracentrotus lividus & Oral diameter \\
Astropecten aranciacus & Total length $\dagger$ \\
Coscinasterias tenuispina & Total length $\dagger$ \\
Echinaster sepositus & Total length $\dagger$ \\
Peltaster placenta & Total length $\dagger$ \\
\hline
\end{tabular}


Table A4. Definition of the levels of the biological categories Trophic Group, Feeding Strategy and Capture Tools, as used in this study to characterize the feeding biology of the species of potential predators.

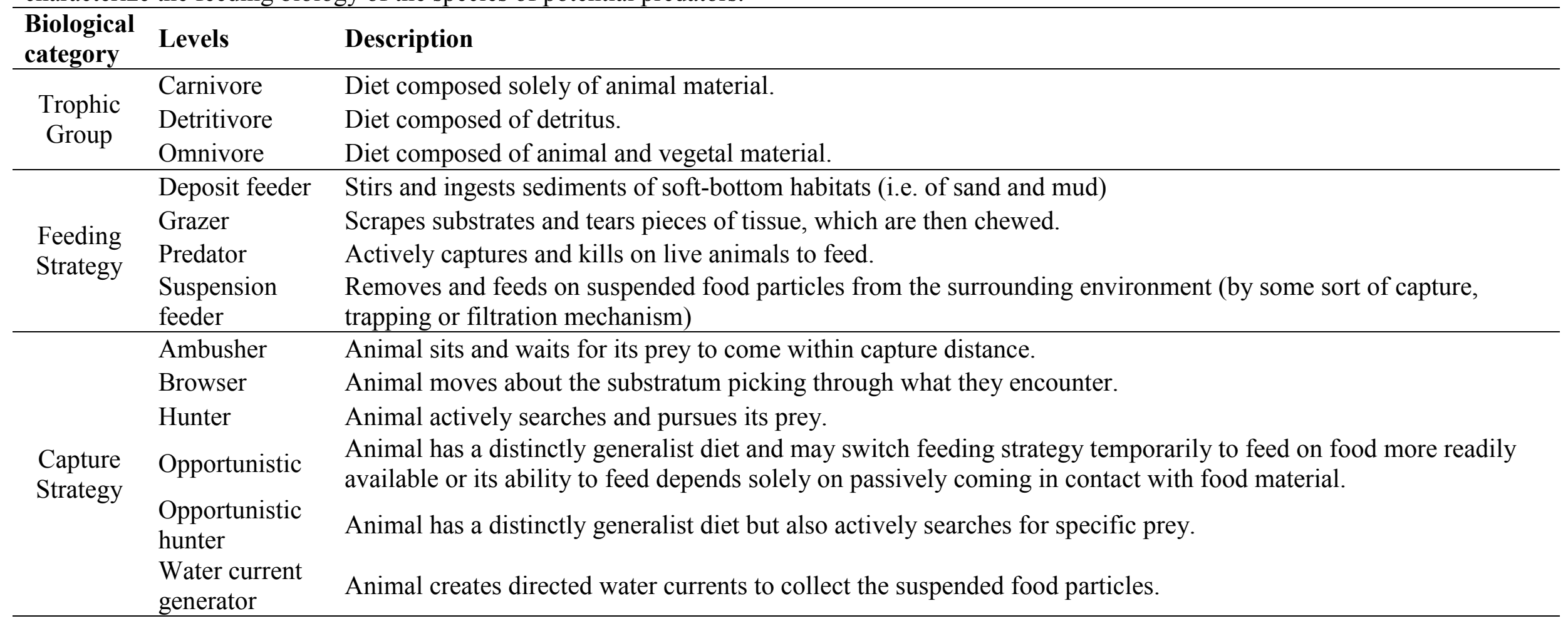




\subsection{Appendix references}

Abelló, P.; Valladares, F.J. \& Castellón, A. (1998). Analysis of the structure of decapod crustacean assemblages off the Catalan coast (North-West Mediterranean). Marine Biology 98: 39-49.

Baeta, M. \& Ramón, M. (2013). Feeding ecology of three species of Astropecten (Asteroidea) coexisting on shallow sandy bottoms of the northwestern Mediterranean Sea. Marine biology 160(11): 2781-2795.

Bell, M.; Tuck, I. \& Dobby, H. (2013). Nephrops species. In: Phillips, B. (ed.) Lobsters: Biology, Management, Aquaculture \& Fisheries, Second Edition. Wiley-Blackwell Publishing, Oxford, pp. 357-413.

Boletzky, S.V.; Andouche, A. \& Bonnaud-Ponticelli, L. (2016). A developmental table of embryogenesis in Sepia officinalis. Vie et Milieu 66(1): 11-23.

Caine, E.A. (1975). Feeding and masticatory structures of selected Anomura (Crustacea). Journal of Experimental Marine Biology and Ecology 18: 277-301.

Caron, A.; Desrosiers, G.; Olive, P.J.W.; Retière, C. \& Nozais, C. (2004). Comparison of diet and feeding activity of two polychaetes, Nephtys caeca (Fabricius) and Nereis virens (Sars), in an estuarine intertidal environment in Québec, Canada. Journal of Experimental Marine Biology and Ecology 304: 225- 242.

Chaves, M.L.; Horta, M.S.; Chainho, P.; Costa, M.J. \& Costa, J.L. (2010). New additions to the feeding ecology of Carcinus maenas (L., 1758) in a South-western Europe estuary (Portugal). Cahiers de Biologie Marine 51: 229-238.

Chiavarini, S.; Massanisso, P.; Nicolai, P.; Nobili, C. \& Morabito, R. (2003). Butyltins concentration levels and imposex occurrence in snails from the Sicilian coasts (Italy). Chemosphere 50: 311-319.

Chintiroglou, C. \& Koukouras, A. (1991). Observations on the feedings habits of Calliactis parasitica (Couch, 1842), Anthozoa, Cnidaria. Oceanologica Acta 14(4): 389-396. 
Cordeiro, R.; Borges, P.J.; Martins, M.F.A. \& Ávila, P.S. (2015). Checklist of the littoral gastropods (Mollusca Gastropoda) from the Archipelago of the Azores (NE Atlantic). Biodiversity Journal 6 (4): 855-900.

Cristo, M. \& Cartes, J.E. (1998). A comparative study of the feeding ecology of Nephrops norvegicus L. (Decapoda: Nephropidae) in the bathyal Mediterranean and the adjacent Atlantic. Scientia Marina 62(Supl.1): 81-90.

Cronin, E.R. \& Seymour, R.S. (2000). Respiration of the eggs of the giant cuttlefish Sepia apama. Marine Biology 136(5): 863-870.

Dworschak, P.C. (1987). Feeding behaviour of Upogebia pusilla and Callianassa tyrrhena (Crustacea, Decapoda, Thalassinidea). Investigación Pesquera 51(Supl.1): 421429.

Encyclopedia of Life. Available from http://www.eol.org. Accessed 29 Sept 2016.

Fauchald, K. \& Jumars, P.A. (1979). The diet of worms: a study of polychaete feeding guilds. Oceanography and Marine Biology, Annual Review 17:193-284.

Ferguson, J.C. (1969). Feeding activity in Echinaster and its induction with dissolved nutrients. Biological Bulletin 136: 374-384.

Gibson, R. (1995). Nemertean genera and species of the world: an annotated checklist of original names and description citations, synonyms, current taxonomic status, habitats and recorded zoogeographic distribution. Journal of Natural History 29: 271561.

Güler, M. \& Lök, A. (2015). Foraging behaviors of sea stars, Marthasterias glacialis and Astropecten aranciacus (Asteroidea) and predator-prey interactions with warty venus clam, Venus verrucosa (Bivalvia). Journal of Experimental Marine Biology and Ecology 465: 99-106.

Harrison, M.K. \& Crespi, B.J. (1999). Phylogenetics of Cancer crabs (Crustacea: Decapoda: Brachyura). Molecular Phylogenetics and Evolution 12(2): 186-199.

Heller, J. (2015). Sea snails: A natural history. Springer International Publishing, Switzerland. 
Jangoux, M. \& Lawrence, J.M. (1982). Echinoderm nutrition. CRC Press, Balkema, Rotterdam.

Kunze, J. \& Anderson, D.T. (1979). Functional morphology of the mouthparts and gastric mill in the hermit crabs Clibanarius taeniatus (Milne Edwards), Clibanarius virescens (Krauss), Paguristes squamosus McCulloch and Dardanus setifer (MilneEdwards)(Anomura: Paguridae). Marine and Freshwater Research 30: 683-722.

Lawrence, J. M. (ed.) (2013). Starfish: biology and ecology of the Asteroidea. Johns Hopkins University Press, Baltimore, Maryland.

Lawton, P. \& Hughes, R.N. (1985). Foraging behaviour of the crab Cancer pagurus feeding on the gastropods Nucella lapillus and Littorina littorea: comparisons with optimal foraging theory. Marine Ecology Progress Series 23: 143-154

McDermott, J.J. \& Roe, P. (1985). Food, feeding behavior and feeding ecology of nemerteans. American Zoologist 25: 113-125.

Micael, J.; Alves, M.J.; Jones, M.B. \& Costa, A.C. (2012). Diversity of shallow-water asteroids (Echinodermata) in the Azorean Archipelago. Marine Biodiversity Records 5: e49.

Minin, K.V. (2012). Vertical trends in morphological variability of sea urchins of the genus Echinus from the Northeast Atlantic and Arctic. Paleontological Journal 46(8): 9.

Baeta, M.; Galimany, E. \& Ramón, M. (2016). Growth and reproductive biology of the sea star Astropecten aranciacus (Echinodermata, Asteroidea) on the continental shelf of the Catalan Sea (northwestern Mediterranean). Helgoland Marine Research doi:10.1186/s10152-016-0453-z.

Morton, B; Peharda, M. \& Harper, E.M. (2007). Drilling and chipping patterns of bivalve prey shell penetration by Hexaplex trunculus (Mollusca: Gastropoda: Muricidae). Journal of the Marine Biological Association of the United Kingdom 87: 933-940.

Mura, M.; \& Orrù, F. (1998). Feeding habits of Parthenope macrochelos (Brachyura, Parthenopidae) in the Central-Western Mediterranean Sea. Biologia Marina Mediterranea 5(1): 570-573. 
Norman, M.D.; Finn, J.K. \& Hochberg, F.G. (2016). Family Octopodidae. In: P. Jereb; C.F.E. Roper; M.D. Norman, \& J.K. Finn (eds.) Cephalopods of the world. An annotated and illustrated catalogue of cephalopod species known to date. Volume 3. Octopods and Vampire Squids. FAO Species Catalogue for Fishery Purposes. No. 4, Vol. 3. Rome, FAO. pp. 36-215.

Ropes, J.W. (1968). The feeding habits of the green crab, Carcinus maenas (L.). Fishery Bulletin 67(2): 183-203.

Sardà, F. (1998). Nephrops norvegicus (L.): Comparative biology and fishery in the Mediterranean Sea. Introduction, conclusions and recommendations. Scientia Marina 62(Supl.1): 5-15.

Terribile, K.; \& Schembri, P.J. (2013). Depth distribution of Cidaris cidaris (Linnaeus, 1758) and Stylocidaris affinis (Philippi, 1845) (Echinodermata, Echinoidea) around the Maltese Islands. Rapport Commission Internationale de la Mer Méditerranée 40: 697.

Thiel, M. \& Kruse, I. (2001). Status of the Nemertea as predators in marine ecosystems. Hydrobiologia 456: 21-32.

Villamor, A. \& Becerro, M. (2010). Matching spatial distributions of the sea star Echinaster sepositus and crustose coralline algae in shallow rocky Mediterranean communities. Marine Biology 157: 2241-2241.

Watanabe, J.T. \& Young, C.M. (2006). Feeding habits and phenotypic changes in proboscis length in the southern oyster drill, Stramonita haemastoma (Gastropoda: Muricidae), on Florida sabellariid worm reefs. Marine Biology 148: 1021-1029.

Zatylny, C.; Gagnon, J.; Boucaud-Camou, E. \& Henry, J. (2000). ILME: a waterborne pheromonal peptide released by the eggs of Sepia officinalis. Biochemical and Biophysical Research Communications 275(1): 217-222. 